\title{
Tactics for Transforming the Housing Structure, New Housing Models. Upgrading Novo Maalo, Skopje, Tactics for Transformation of the Housing Texture
}

\author{
Gordan Petrov \\ Faculty of Architecture - Skopje, Ss Cyril and Methodius University of Skopje, Skopje, Republic of Macedonia
}

Citation: Petrov G. [Tactics for Transforming the Housing Stuctur, New Housing Models. Upgrading Novo Maalo, SEE J Archit Des. 2015 Jan 25:2015:10004. [Macedonian http://dx.doi.org/10.3889/seejad.2015.10004

Key words: upgrading; urban fragments; city; bridge; line

Correspondence: Gordan Petrov. Faculty of Architecture Ropje, Ss Cynil and Methodils Universty of Skopje, Skor

Received: 18-Dec-2014; Revised: 25-Dec-2014; Accepted:

Copyright: ๑ 2015 Gordan Petrov. This is an open-access article distributed under the terms of the Creative Commons Attribution License, which permits unrestricted use, distiblion, ace restodion in any medium, provided the

Competing Interests: The author have declared that no competing interests exis.

\section{Abstract}

We are witnessing a dynamic development of our society, which undoubtedly require integration of new architectural concepts that will suit the modern way of life in the city. Subject of analysis and design of this master thesis is the contemporary transformations of urban texture in marginalized areas which undoubtedly belong and are part of the urban fabric, finding an alternative solution for the physical and social devastating processes that are fragmenting and deconstructing the residential tissue of the city.

The first part of this paper treats topics that indicate different types of upgrading and layering of the urban tissue, followed by a number of historical examples and projects. The next step is chronological and morphological decomposition of Skopje, recognizing the urban fragments in the city and the urban layers created at the end of the XIX and throughout the XX century. The design concept for the chosen fragment is a totally new re-thinking for a possible transformation; it fits the current needs and resolves the existing problems but in the same time it is a recognizable, in terms of that is based on the already processed theories of transformation and reconstruction of the city.

The project proposes to retain the existing structure of the neighborhood (Novo Maalo), not because it is in good physical condition, but because of the very people and for their convenience of the human scale space, the atmosphere that reigns in the neighborhood, a sense of belonging and of course, the social aspect of the neighborhood. It allows through tactics of upgrading or adding another, parallel level of the new neighborhood, shape defined by the street pattern of the neighborhood. The line bridge structure functionally connects two parts of the city, also retaining and complementing quality of life and finally giving a response to the current destructive processes of the housing texture in the neighborhood. 
Универзитет "Св. Кирил и Методиј”

Архитектонски фракултет

Скопје

Магистерски труд:

TEMA: Тактики на трансформирање на станбената текстура, нови модели на домување

НАСЛОВ: Надградувајќи го Ново маало, Скопје, тактики на трансформирање на станбената текстура

Текстуален дел

Ментор:

Кандидат:

Проф. Д-р Минас Бакалчев

Петров Гордан

Скопје, 2013 
Комисија:

Ментор: Профр. Д-р Минас Бакалчев

Претседател: Проф. Д-р Зорица Блажевска

Член 1: Проф. Д-р Страхиња Трпевски

Член 2: Проф. Д-р Владимир Арсовски 


\section{АПСТРАКТ:}

Сведоци сме на еден динамичен развој на општеството, кое несомнено има потреба од интегрирање на нови архитектонски концепти, кои ќе одговараат на современиот начин на живот во градот. Предмет на анализа и проектирање во овој магистерски труд се современите трансформации на станбената текстура во маргинализираните зони кои несомнено припаѓаат и се дел од градското ткиво, како и наоѓање на алтернативно решение за физички девастирачките и социјално разградувачките процеси кои го фррагментираат и деконструираат основното станбено ткиво на градот. Во првиот дел од овој труд се обработуваат теми кои укажуваат на најразлични типови на надградување, наслојување, суперпонирање на градското ткиво, проследено преку низа историски примери и проекти. Следниот чекор е морфолошко-хронолошката декомпозиција на градот Скопје, каде што се препознаваат урбаните фрагменти во градот, односно урбаните слоеви создадени кон крајот на XIX и во текот $\mathrm{XX}$ век. Начинот на кој се приоѓа кон разгледување на избраниот фрагмент од градот (Ново маало) е нов, од аспект на тоа дека одговара на моменталните потреби и постојните проблеми кои се среќаваат во Ново маало, но во исто време и препознатлив, од аспект на тоа дека се базира на веќе обработени теории за трансформација и реконнструкција на градот. Проектот предлага да се задржи постојната, ситна структура на Ново маало, не затоа што е во добра фризичка состојба, туку поради фактот што на самите жители им годи човекомерноста на просторот, атмосфрерата која владее во маалото, чувството на припадност и секако, социјалниот аспект во маалото. Тоа се овозможува преку тактика на надградување, односно додавање на уште едно, паралелно ниво на Ново маало, форма која произлегува од уличниот модел на маалото. Линиската мостовска структура која е предвидена, функционално поврзува два дела од градот, воедно ги задржува и ги надополнува животните квалитети и најпосле дава еден одговор на стихијните процеси на згуснување на станбената текстура во маалото.

Клучни зборови: надградување, урбани фррагменти, град, мост, линиска структура 


\section{Содржина на магистарски труд:}

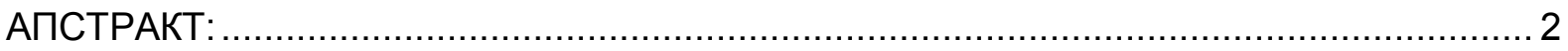

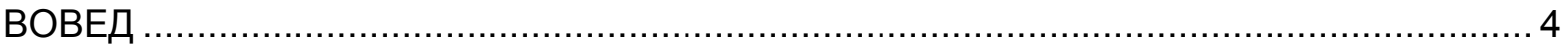

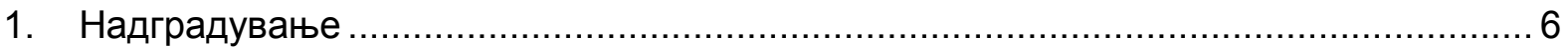

1.1. Историјата на Троја - наслојување/стратификација ....................................... 7

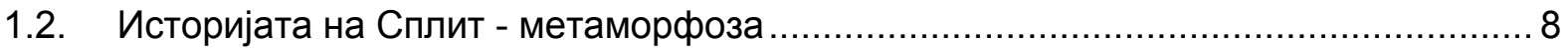

1.3. Идеите на просторен град на архитектот Јона Фридман - суперпонирање во

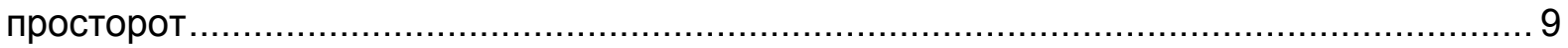

1.4. Констант Нувенхајс - Нов Вавилон - суперпонирање во територија ................. 11

1.5. Населба Мичурин, Скопје - од функционалистички град до град на

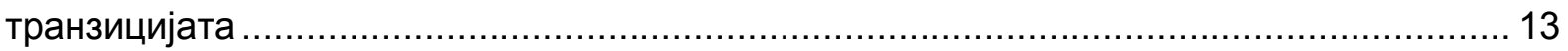

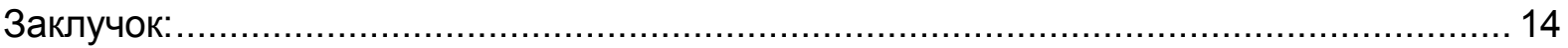

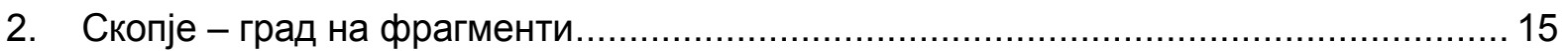

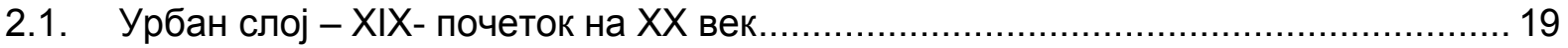

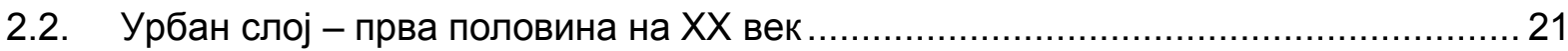

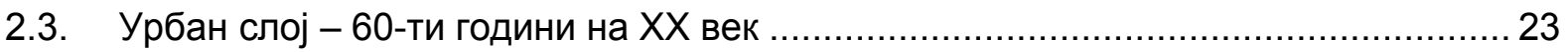

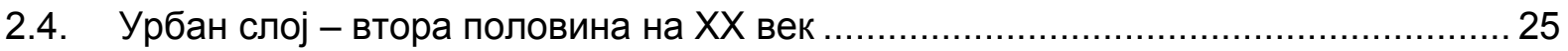

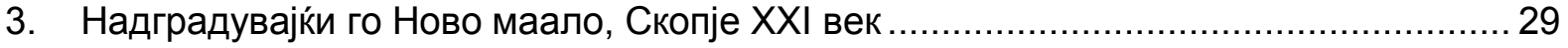

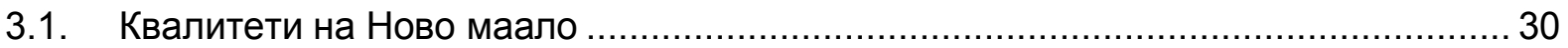

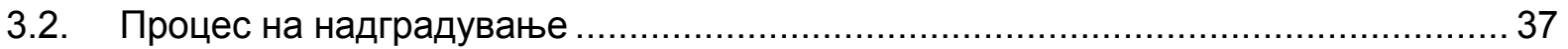

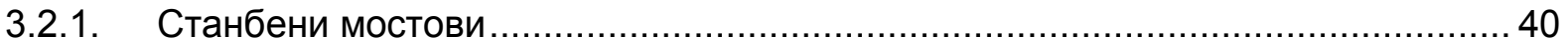

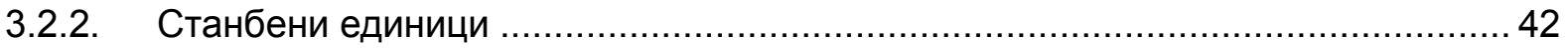

3.2.3. Пешачка и велосипедска мост/патека - конектор на кејот на реката Вардар со

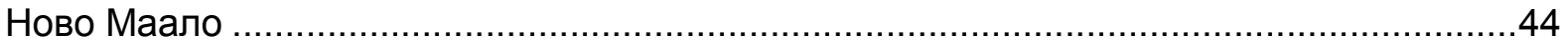

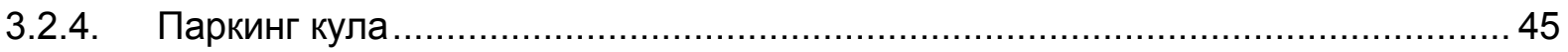

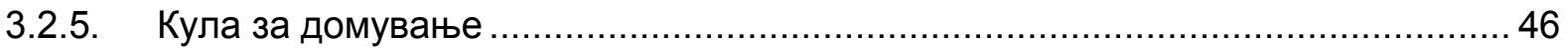

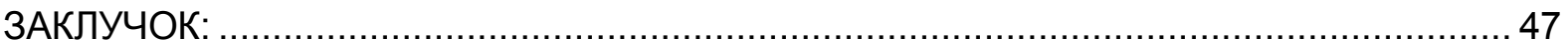

БИБЛИОГРАФИЈА:

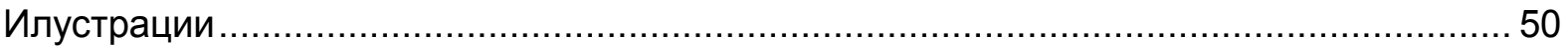




\section{ВОВЕД}

Скопје денес е град на противречности, надежи и разочарувања, визии и ревизии, утопии и дистопии. Но токму таквата сложена и противречна состојба на градот на почетокот на XXI век, после еден век модернизации, не се повикува на едно повтемелено истражување на ефектите и феномените на модернизацијата, пост-социјалистчката транзиција и современите посттранзиционо архитектонски зафати. Движејќи се помеѓу крајностите, она што е слабост можеме да го направиме предност, она што е обично да стане необично, она што е секојдневно да стане оригинално.

Неконтролираното и хаотично згуснување и трансформирање на физичката и социјалната структура на градот е видлив израз на долготрајната постсоцијалистичка транзиција. Некогашните препознатливи делови на градот во налетот на новите просторни и социјални процеси како и на новите станбени потреби ја губат јасната урбана морфологија и архитектонска типологија. Нивните некогашни станбени квалитети неповратно се губат. Како можеме да одовориме на новите потреби, а истовремено да ги задржиме и развиеме постојните квалитети?

Цел на проектот се истовзаеемените трансформации на станбената текстура во просторно и социјално маргинализирани зони. На примерот на Ново Маало, Скопје ова истражување ќе понуди различни модели на трансформирање, зголемување на неговиот просторно програмски капацитет, со задржување на неговите животни вредности. 
Преку постапка на надградување, суперпонирање на линеарни формации произлезени од основниот уличен модел на Ново Маало, возможно е програмско и просторно надградување и истовремено да одржиме и оптимално ниво на згуснување на постојната станбена структура. На тој начин се создава една нова просторна конфигурација, колективна форма, која произлегува од урбаната морфологија на Ново Маало но истовремено опстојува независно. Така преку линиски надградби можеме да одговориме на стихијните процеси на згуснување на станбената тектура на маалото, да воведеме нови станбени модели и истовремено да ги задржиме постојните просторни и социјални модели на живеење.

Предмет на проектот е станбената текстура на еден од препознатливите урбани фррагменти: Ново Маало, Скопје

Ново Маало се забележува за прв пат во градските ситуации од почетокот на дваесетиот век. Неговата градска морфологија лесно може да се издвои од традиционалните схеми на органски град и од планираните схеми на модерниот град. Тое е своевидна регулација и спонтаност. Прави улици кои конвергираат во неправилни исечоци со куќи кои ги задржуваат традиционалните модели на живеење и фасади со европски референци. Ново Маало еднаш беше пример на спојување на спротивносите на регуларните исечоци и традиционалните типологии на куќи. Дали постоеле 100 години од неговото опстојување на праот на неговото исчезнување можеме да воспоставиме нов дијалог помеѓу пазарните закони и потреби на згуснување и наеговите автентични вредности? 


\section{1. Надградување}

Надградување како поим се употребува во многу области во секојдневниот живот на човекот. Употребуван е за најразлични ситуации и неговото значење се менува во зависност каде е употребен. Заедничко е тоа што во секоја од тие ситуации овој поим се однесува на некој тип на суперпонирање, наслојување, поставување врз нешто што постои...

Во архитектурата, процесот на надградување би можел да има повеќе дефиниции. Да започнеме од онаа асоцијативната, процес на фризичко надградување, односно поставување „едно над друго“. Но овој процес не секогаш се темели на оваа основна дефиниција. Со подетално разгледување на различните техники и начини на употреба на овој процес и поим, може да се забележат повеќе начини на негова интерпретација, односно повеќе начини на надградување. Оваа постапка на надградување, односно наслојување врз нешто што веќе постои и функционира како една целина, најдобро можеме да го објасниме преку конкретни примери кои имаат за цел да ги прикажат различните начини и постапки на делување преку постапка на надградување. 


\section{1. Историјата на Троја - наслојување/стратификација}

Историјата на Троја може да се сумира како опис на секвенци на утврдени населби, изградени една врз друга, на екстремно мала територија. Потекнува од неолитското и ранобронзеното доба (3000г. п.н.е. - 2500г. н.е.) чиј континуиран развој тече низ серија слоеви, дефинирани од I-IX, се до римската последна фраза. ${ }^{1}$

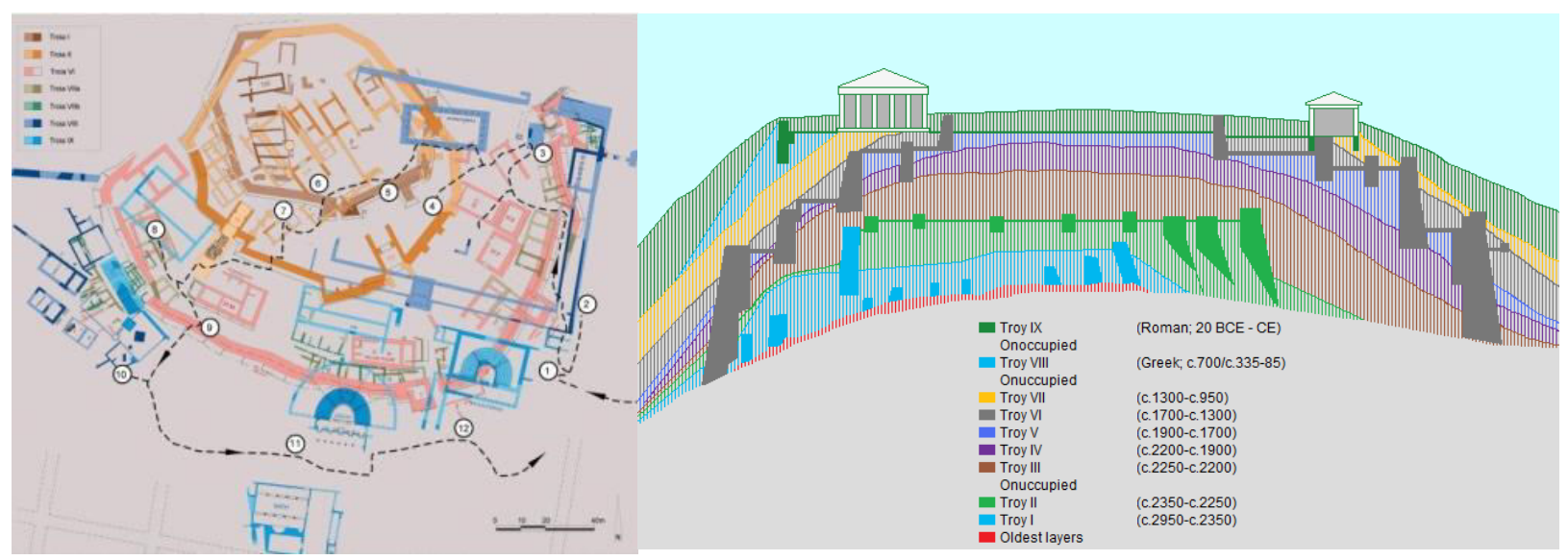

Сл. 1 Археолошки слоеви на градот Троја

Понатамошното истражување овозможува диференцирање на почетните девет слоеви во 30 стратуми, животни артифициелна стратификација на различни цивилизациски слоеви. Наслојувањето е урбан процес кој во помала или поголема мерка се препознава секој историски град. Во примерот на Троја е карактеристично тоа што секој слој се формира врз руиниран или уништен, поради природни или други катастрофи, урбан дел од градот.

\footnotetext{
${ }^{1}$ Ekrem Akurgal, Ancient Civilizations and Ruins of Turkey, Net Turistiik Yayinlar A.S.1990, pp. 47-62
} 


\section{2. Историјата на Сплит - метаморфоза}

Примерот на Сплит е посебно интересен во фрормирањето на критичкиот дискурс на модерниот град во кој се демонстираше двојноста на формата и фрункцијата. За низа автори тоа беше историски модел, кој укажуваше за можното редефинирање на односот на фрормата и фринкцијата во современиот град, преку капацитетот на формата да прифрати различни фрункции (Бакема, Херман Хертзбергер, Алдо Роси).

Диоклецијановата палата во Сплит е градена како царска резиденција, по модел на воен логор (215/175-180). После смртта на Диоклециан, палатата постепено се деградира, трансформирајќи се во една средновековна урбана агломерација. Така она што некогаш било дел од структурата на палатата, сега е дел од текстурата на градот.

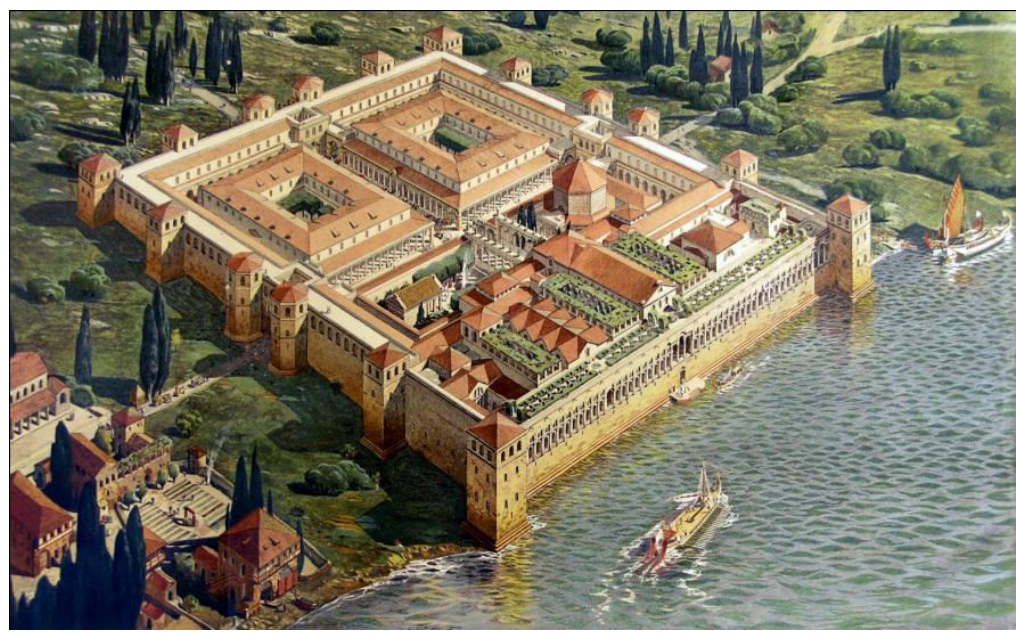

Сл. 2 Диоклецијанова палата - Сплит

Физичката структура на некогашната палата, целосно е превземена како таква, добивајќи нова намена преку целосна акомодација на градот во дадената фрорма. Во процесот на претворување, ги препознаваме фррагментите кои 
асоцираат на старото, но не можеме да ги издвоиме од текстурата на градот процесот е иверзибилен. ${ }^{2}$

\section{3. Идеите на просторен град на архитектот Јона Фридман - суперпонирање во просторот}

Јона Фидман е роден во 1923 година во Будимпешта (Унгарија). Тој живее и твори во Париз (Франција). Како архитект, тој станува познат со неговиот манифест „Мобилна Архитектура“ и неговата идеа за поинаков пристап на урбаниот раст на градовите во неговата идеа за „Просторен град“.

Работејќи на идеата и принципите на „Просторниот град“, Фридман целел кон тоа да обезбеди максимална фрлексибилност преку огромни суперструктури кои би се поставиле над постоечки градови и други локации. Идните жители се слободни да ги изградат своите живеалишта во рамките на овие структури.

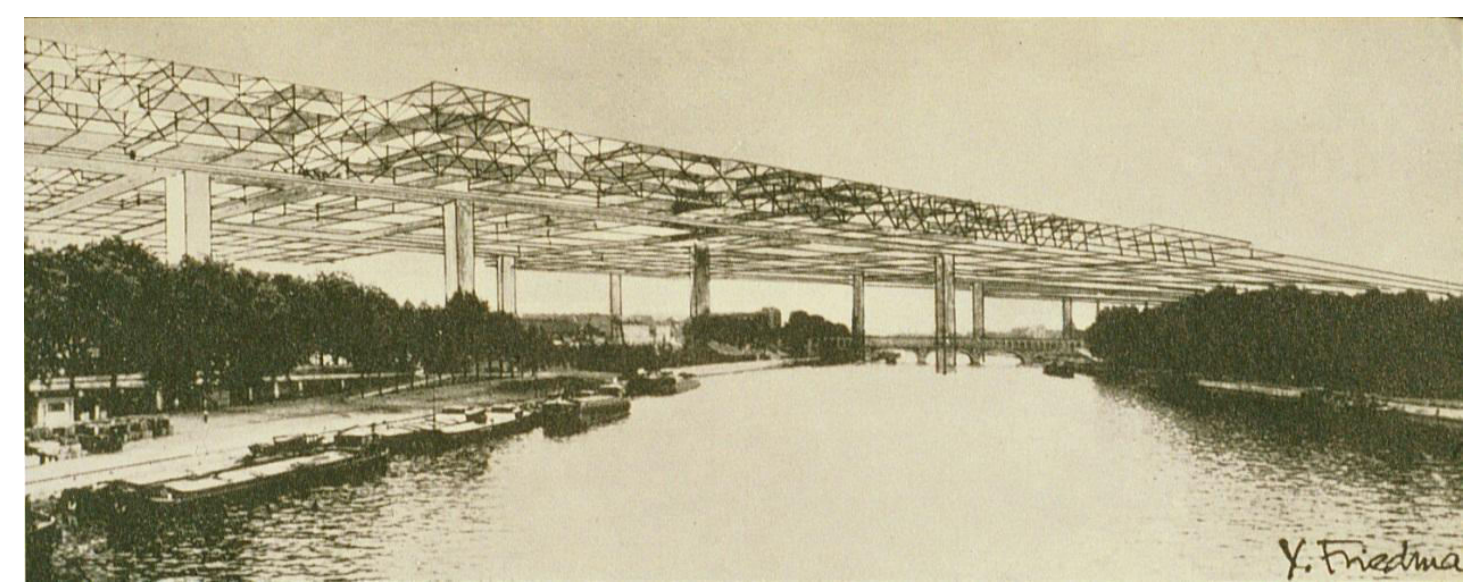

Сл. 3 Просторна претстава за градот на Јона Фридман

Фридман имал за цел, на различни локации, да ги објасни предностите на идеата, воедно и да упати кон тоа дека не е нужно да се уништат постарите делови од градовите за да се креираат нови живеалишта. Со самото

\footnotetext{
${ }^{2}$ Бакалчев, Минас, Домување како урбан фррагмент. Необјавена докторска дисертација. Архитектонски факултет Скопје. Универзитет Св. Кирил и Методиј, Скопје, стр.35-36
} 
надградување на градовите тој го спречува ширењето на градот надвор од своите рамки, односно градот почнува да се шири по вертикала, да се надградува.

Просторниот град е повеќе-слоен структурален скелет (мрежа) на потпорници кои можат фрлексибилно да се прилагодат според желбата на жителите. Структурата се носи на столбови кои се поставени на интервали од 40-60 метри. Мрежата е составена од модул 6 × 6 метри каде што можат да се сместат сите предвидени функции. Единствен ограничувачки параметар е тоа што максималната исполнетост на оваа структура не смее да надмине $50 \%$ се со цел светлината да продира и во најдолниот слој на градот.

Поставувањето на просторниот град на повеќе независни нивои, еден врз друг, го детерминира просторното планирање на градот, како преку функционална и визуелна, така и преку програмска гледна точка. Суперпонирањето на слоевите би требало да овозможи изградба на индустрија, домување или комерцијални дејности на една иста површина. На тој начин просторниот град формира, како што би рекол Јона Фридман, “артифициелна топографија“, висечки град или мрежа во просторот кои ја отцртуваат новата картографија на теренот со помош на континуирана и непрекината мрежа.

Идеите и принципите за "Просторниот град“ се претставени од страна на Јона Фридман во 1958 година. Истата година тој ги претставува и “Просторен Тунис“ и “Просторен Париз“. Ваквата идеја понатаму претставува појдовна точка за проектите на "Архиграм“ во 1963 година, како и пристапот на јапонските метаболисти во периодот од 1960-та до 1970-та година. 


\section{4. Констант Нувенхајс - Нов Вавилон - суперпонирање во територија}

Констант Нувенхајс (1920-2005) е Холандски уметник и самоук архитект, еден од основачите на Situationist International фоормирана во 1957 година. Тој е познат по неговиот утописки проект, Нов Вавилон, започнат во 1956 година на

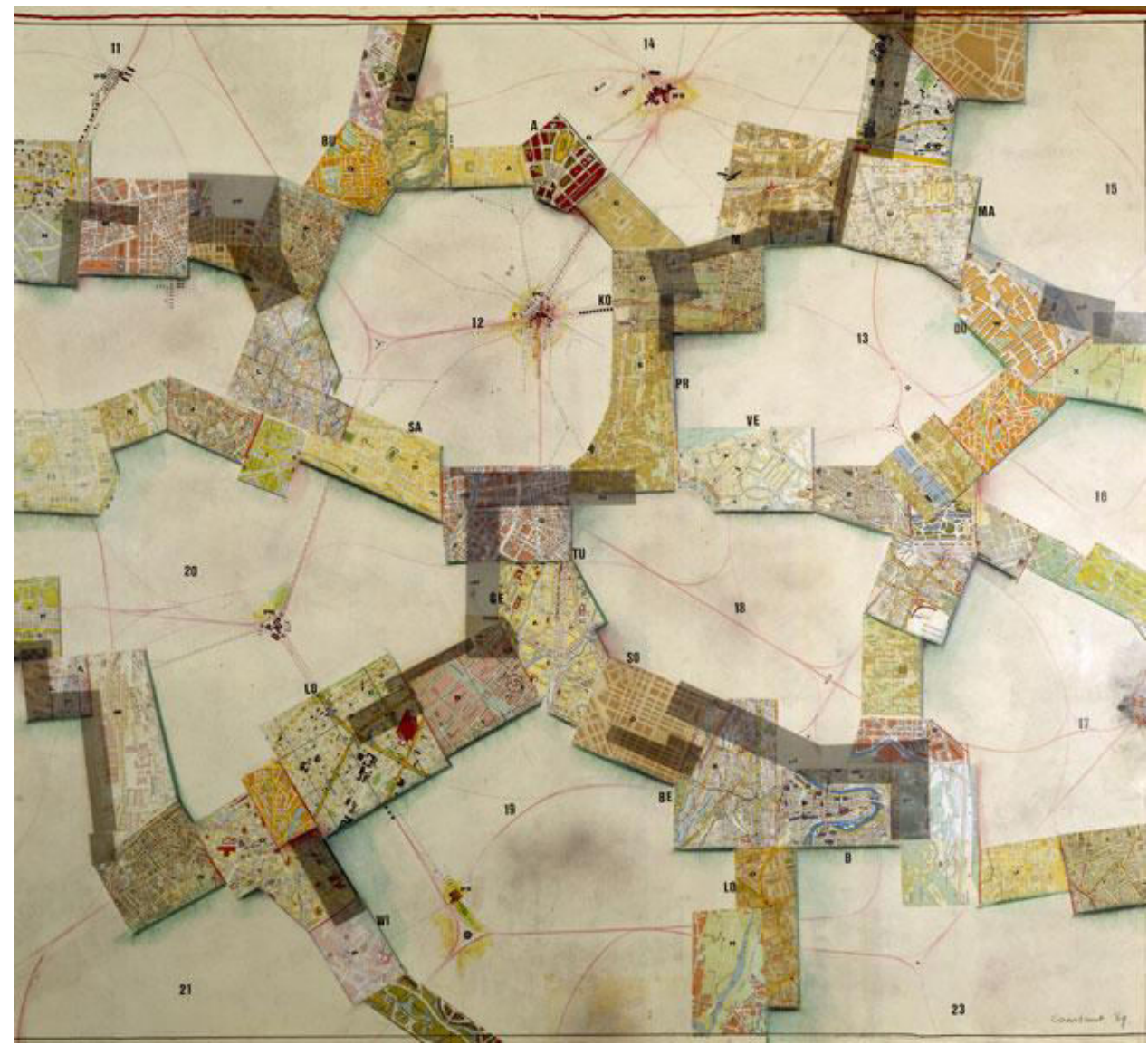

Сл. 4 Цртеж на концептот за Нов Вавилон

кој тој работел скоро дваесет години. Констант бил еден од теоретските двигатели на Situationist International заедно со Геј Дебор (1931-1994), но поради дијаметрално спротивните ставови, Констант ја напуштил групата. 
Проектиран како град во кој жителите се одрекуваат од работа, Нов Вавилон е град базиран на тотална автоматизација, како и на колективна сопственост на земјиштето. Без работа, жителите би биле слободни да се движат наоколу, инспириран од цигански логор и проектиран да го симплифицира номадскиот животен стил. Поделен во серија на меѓусебно поврзани сектори, Нов Вавилон фрункционира како мрежа од колективни сервиси и транспорт. Преку многубројни модели, цртежи и колажи, Констант ги проучувал различните сектори, кои лебдат над површината, носени од столбови, меѓусебно поврзани со мостови и патеки. Нов Вавилон се фокусира да создаде простор каде што секој аспект во градот би можел да се контролира од самите жители, односно тие самите да можат да креираат свои атмосфрери и ситации во дадена структура. Целта е да се создаде динамична околина која би била лесно адабтибилна и менувана, дозволувајќи на жителите да ја истражуваат својата креативност преку игра и интеракција.

Додека фризичката реалност на градот била проучувана преку цртежи и макети, архитектурата како сама за себе, била замислена како општествени односи во кои Констант ја критикувал буржоазијата односно утилитарното општество. Степенот до кој деталите во овој проект за град се разработени, како и Константовиот дискурс ни покажуваат дека тој го гледал овој проект како конкретно решение за град на иднината, а не само како полемички проект кој се сведува само на утописка идеја. ${ }^{3}$

\footnotetext{
${ }^{3}$ Wigley, Mark; Constant; Witte de With, Constant's New Babylon: The Hyper-architecture of Desire,010 Publishers, 2009
} 


\section{5. Населба Мичурин, Скопје - од функционалистички град до град на транзицијата}

Населбата Мичурин е фрагмент од Скопје кој е планиран во педесетите години на дваесеттиот век. Во тој период започнува еден нов циклус во урбаното планирање, каде што Л. Кубеш е избран да раководи со целокупниот проект и да му даде нов лик на Скопје. Градот претставува систем на реони во кои се вклучени сите неопходни културно административни и спортски содржини. Станбените реони се делат на станбени блокови, со точно дефриниран карактер на сообраќајна мрежа, додека пак станбените блокови со парковите чинат една целина. Во овој план за градот се исклучуваат затворените периметарски блокови и се предвидуваат слободностоечки линиски објекти. Таков е примерот на населбата Мичурин, каде што се планирани и изведени слободностоечки станбени линиски објекти кои во прв момент биле на приземје плус два ката. Како што минувале годините се јавило потреба од простор плус, истите се доградуваат и надградуваат. Со самото тоа нивната димензија во основа се зголемува, како и висината, која сега е приземје плус пет ката.
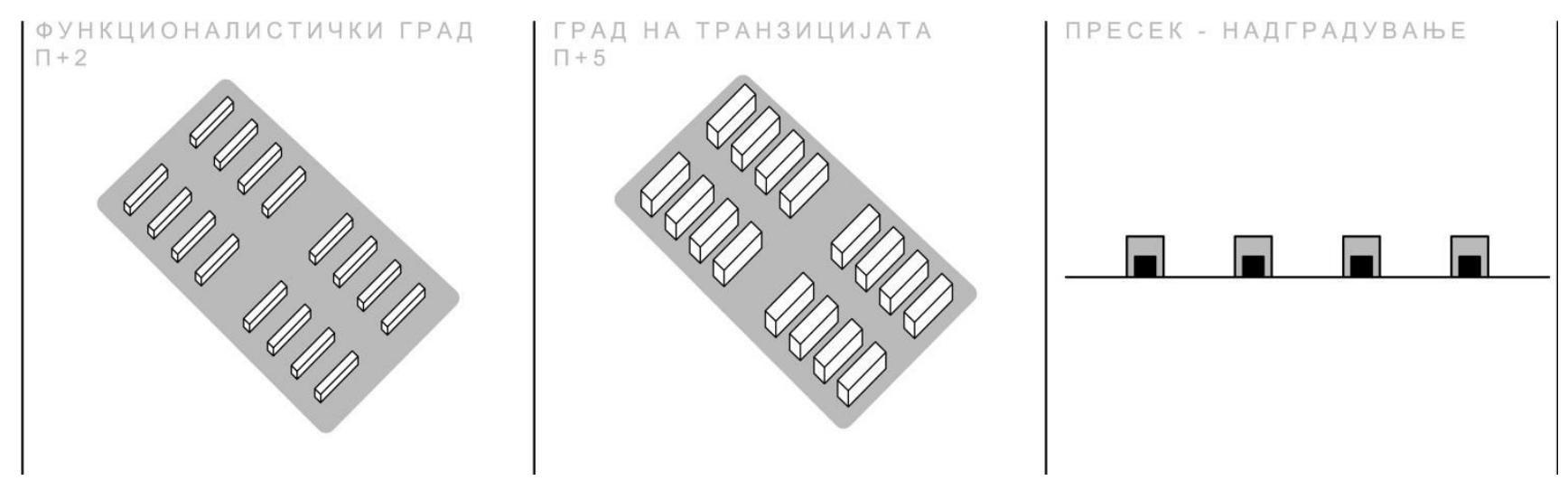

Сл. 5 Над-до-градба на објект во населба Мичурин 


\section{Заклучок:}

Начинот на суперпонирање на различните слоеви овозможува да се согледа диверзитетот и комплексноста на самиот процес на надградување. Секој од наведените примери наведува на различен принцип на надградување инициран од постојните проблеми и ситуации, независно дали се тоа проблеми во општествената заедница и потреба од простор плус или пак проблеми и ситуации настанати низ историјата.
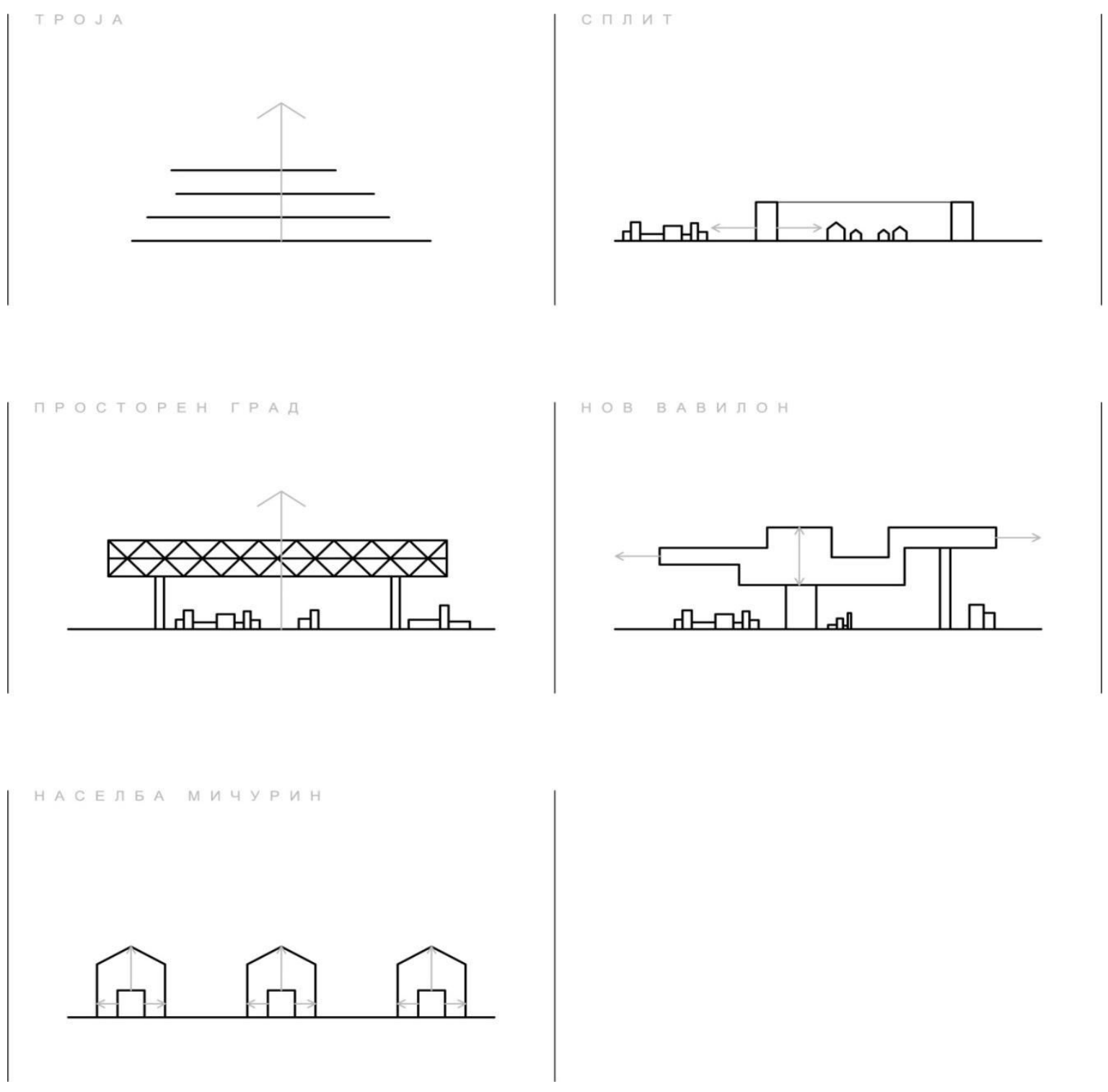

Сл. 6 Дијаграми за различните типови на надградување 


\section{2. Скопје - град на фррагменти}

Насочувајќи го истражувањето кон Скопје, соочени сме со комплексно наслојување на градот, а со самото тоа сведоци сме на неизбежен процес на трансформација на градот.

Сегашната слика на Скопје ни укажува дека постои комплексна стратификација од диференцијални слоеви. Таквите фрагменти од градот, наведува на процес на промени кој претходел во минатото. Преку декомпозиција на на историските и морфолошките процеси, кои ја создаваат денешната слика на градот, можеме да ја согледаме неговата фррагментарна основа.

Скопје влегува во категоријата на балкански традиционален град, кој минал низ многу процеси на трансформација, кои всушност го означуваат проектот на модернизацијата.

Архитектонските трансформации на Скопје според истражувањето на Профр. М.Бакалчев, ги следиме преку глобалните трансформации на еден урбан систем означен како традиционален балкански град во XIX и XX век. Процесот на трансформација во овој период можеме да го препознаеме, прво, како процес во рамките на Отоманската империја, во кој референтна рамка е постојниот урбан модел и второ, како урбана политика на новите национални држави во фрормулирање на сопствениот идентитет. Овој процес изразува двојна тенденција на вестернизација и деотоманизација.

Во минатото просторните трансформации на Отоманскиот град се движеа преку една доминантна урбана тема која го подразбираше повеќекултурниот состав, конституиран како мозаик на субкултури. Така во морфолошка смисла 
градот кој е поделен на различни субкултури со сопствена препознатлива територија и можност за создавање на дистинктивни животни стилови ќе го наречеме град-мозаик. Низа урбани потфати беа преземени за да дефинираат една друга унитарна претстава на градот. Идеалниот град кој се посакуваше беше негација на традиционалниот, сугериран преку моделот на tabula rasa.

Според Проф. Минас Бакалчев, Скопје ги следи истите процеси на дисолуција и повторна обнова на градот преку процесот на модернизација. Радикалните просторни реформи се појавија после 1920 година, кога Отоманската империја, дефинитивно се повлекува од Балканскиот Полуостров. Дотогашните процеси на модернизација се водеа преку инкорпорирање во постојниот урбан ред. Двесетиот век го воведе унитарниот проект: прво преку процесот на вестернизација/де-отоманизација и стратегијата на "tabula rasa"; второ, преку воведување на функционалистичката доктрина во втората половина на XX век, што доведе до дисолуција на конвенционалните просторни модели. ${ }^{4}$

Така на планот на Скопје можеме да диференцираме три принципиелни слоја:

- град-мозаик на субкултури, традиционален балкански град

- унитарен модел, реконструкција кон европски тип

- унитарен модел, реконструкција кон европски тип

\footnotetext{
${ }^{4}$ Бакалчев, Минас, Домување како урбан фррагмент. Необјавена докторска дисертација. Архитектонски факултет Скопје. Универзитет Св. Кирил и Методиј, Скопје, стр.42-45
} 
Трансформацијата на Скопје низ историјата и имплементираните урбанистички планови, постојано ја менувале основата на градот, па така со текот на времето се создравале фрагменти кои ја формираат денешната слика за Скопје. Вклучувањето на Скопје во составот на Србија, 1914, ја промовира новата идеја на градот (Д.Т. Леко, 1914). Скопје во состав на Југославија (Кралството на Србија, Хрватска и Словенија) се рефрлектира во континуитет на проектот на европеизација на градот (Ј.Михајловиќ, 1929). Скопје како главен град на Народна Република Македонија во состав на Федеративна Народна Република Југославија (1949), носи нов просторен концепт на функционалистички град (Л.Кубеш, 1948). Реконструкцијата на Скопје после катастрофалниот земјотрес (1963), главен град на Социалистичка Република Македонија, во составот на Социјалистичка Федеративна Република Југославија, лидер на неврзаното движење, произлегува од идеите на ревизија на функционалистичкиот град (К.Танге. 1965). Скопје главен град на Република Македонија (2001), после процесот на дисолуција на Југославија и транзиција на политичкиот систем, носи една нова метастабилна урбана ситуација.

Фрагментираната основа на современо Скопје е резултат на историските циклуси во урбаното планирање, споменати погоре. Серијата на различни концепти на секој план, создаваат една сложена хронолошка и морфолошка стратифрикација на фризичката структура. За да го презентираме фрагментарниот карактер на градот, односно фрагментарно да го деконструираме, издвојуваме еден сегмент од централното подрачје на градот, односно радиус од $800 \mathrm{~m}$, во кој можеме да ги дефинираме различните урбани слоеви кои припаќаат во него или пак го тангираат со некој свој дел. Подрачјето 
кое е избрано одговара на два критериуми, во него имаме најголема густина на диференцијалните урбани модели и токму тоа подрачје приближно одговара на зоната на реконструкција на градот во конкурсот за централното подрачје (1964), со кој се завршува низата на урбанистички планови за градот Скопје.

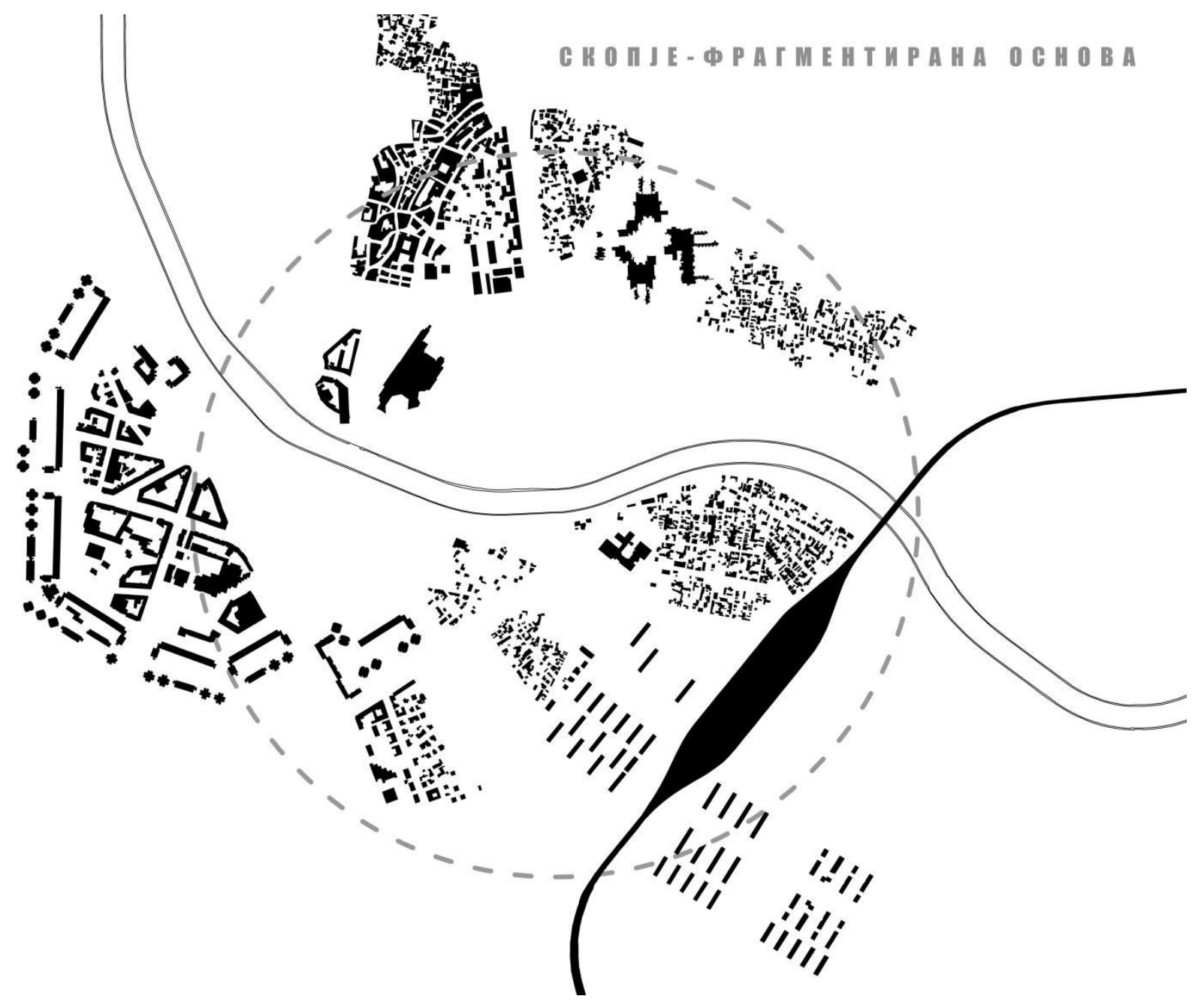

Сл. 7 Фрагментирана основа - Скопје 


\section{1. Урбан слој - XIX- почеток на XX век}

Крајот на XIX век, Скопје сеуште има ирегуларна основа, па така во овој период започнува процесот на фрагментарно регулирање на градот. Во овој период ја регистрираме ортогоналната решетка на Маџир маало во ситуациониот план од крајот на XIX век. Ова е првата планирана екстензија во градот на десниот брег, наменета за преселниците (мухаџирите) после српско-турските војни 1876-1878.

Ново маало со серија суперпонирани регулирани улични планови е регистрирано на ситуациониот план во 1914 година, на границата на Маџир маало и Чивчи маало, на десниот брег. Овие две маала воведуваат еден нов геометриски принцип во урбаната текстура на традиционалниот град.

Крњево маало како и Старата турска чаршија кои што се забележуваат на левиот брег од реката Вардар се урбани фррагменти кои сеуште опстојуваат во денешната слика на Скопје. Првите документирани податоци за Скопската чаршија како трговски центар датираат дури од XII век, но денешниот лик, чаршијата го добила во текот на XIX век. Во време на Отоманското владеење во Скопје, местото забрзано прераснало во најголем трговски дел од градот, во кој се наоѓале 30 џамии, бројни сараи и анови. Како физичка појавност, некои од нив опстојуваат и денес, но функцијата секако е променета. 
Чаршијата е дел од историска аксијала на градот север-југ, односно чаршијата е фррагмент од традиционалниот град.

Според Профр. М.Бакалчев, преку хронолошката сукцесија (time line) на модернизацијата на традиционалниот град, можеме да го изведеме поведението на градот, тенденцијата кон надворешни екстензии и внатрешни трансформации и да препознаеме извесни комплексни урбани зафати, преку интерелационост на фрагментарните инсертирања. ${ }^{5}$

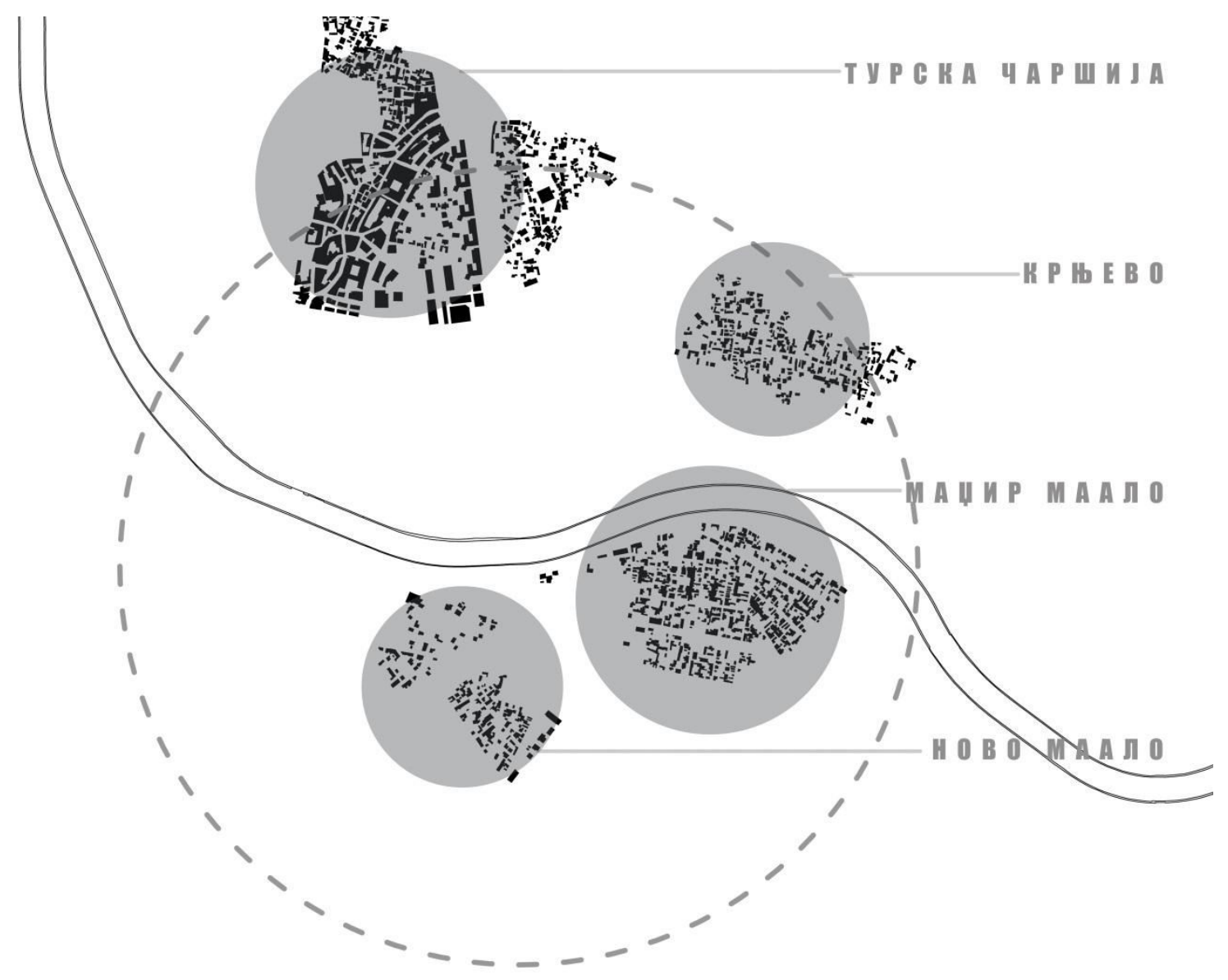

Сл. 8 Скопје - урбан слој XIX-почеток на XX век

\footnotetext{
${ }^{5}$ Бакалчев, Минас, Домување како урбан фррагмент. Необјавена докторска дисертација. Архитектонски факултет Скопје. Универзитет Св. Кирил и Методиј, Скопје, стр.57-60
} 


\section{2. Урбан слој - прва половина на $X X$ век}

Во првата половина на XX век, се воспоставува планирана основа на градот. Блоковските станбени структури на десниот брег на реката Вардар, делумно се забележуваат на Генералниот Регулационен план од 1914 година и Ситуациониот план од 1929 година. Имено, во јужниот дел на градот, или тогашнот “нов дел” од градот, се почитува воведената концепција на блокови, произлезена од радијално-концентричната улична мрежа. Но, самите облици на блокови не се реализирани онака, како што се замислени според планот. За реализација на блоковите повеќе влијание имааат наредните плански документи и регулации, кои се донесувани на одделни делови на градот.

Таков еден плански документ кој е изреализиран е оној, каде што во педесетите години на XX век, се предвидува реконструкција на центарот на Скопје, за што е изработен урбанистички проект. Според наводите на Д.Пенчиќ, овој план предвидува изградба на 2800 станови, пробивање на 4100 м' нови улици, изградба на две основни училишта, 11 објекти од општествен карактер и уредување на внатрешно блоковско зеленило. Применет е систем на врзување, односно дополнување на постојните објекти со нови, во периметрални блокови, и со тоа формирање на уедначени улични фронтови. Во овој проект исклучително значење добиваат плоштадот Маршал Тито и кејот на реката Вардар. Плоштадот има претежно пешачки карактер и е поврзуван преку Камениот мост со Старата Чаршија. ${ }^{6}$

\footnotetext{
${ }^{6}$ Пенчиќ, Дивна, Влијанието на урбанистичките планови врз дисконтинуираната просторна транзиција на градот Скопје во двесеттиот век, необјавена докторска дисертација, Архитектонски факултет Скопје, Универзитет СВ. Кирил и Методиј, Скопје, 2011, стр.16-120
} 


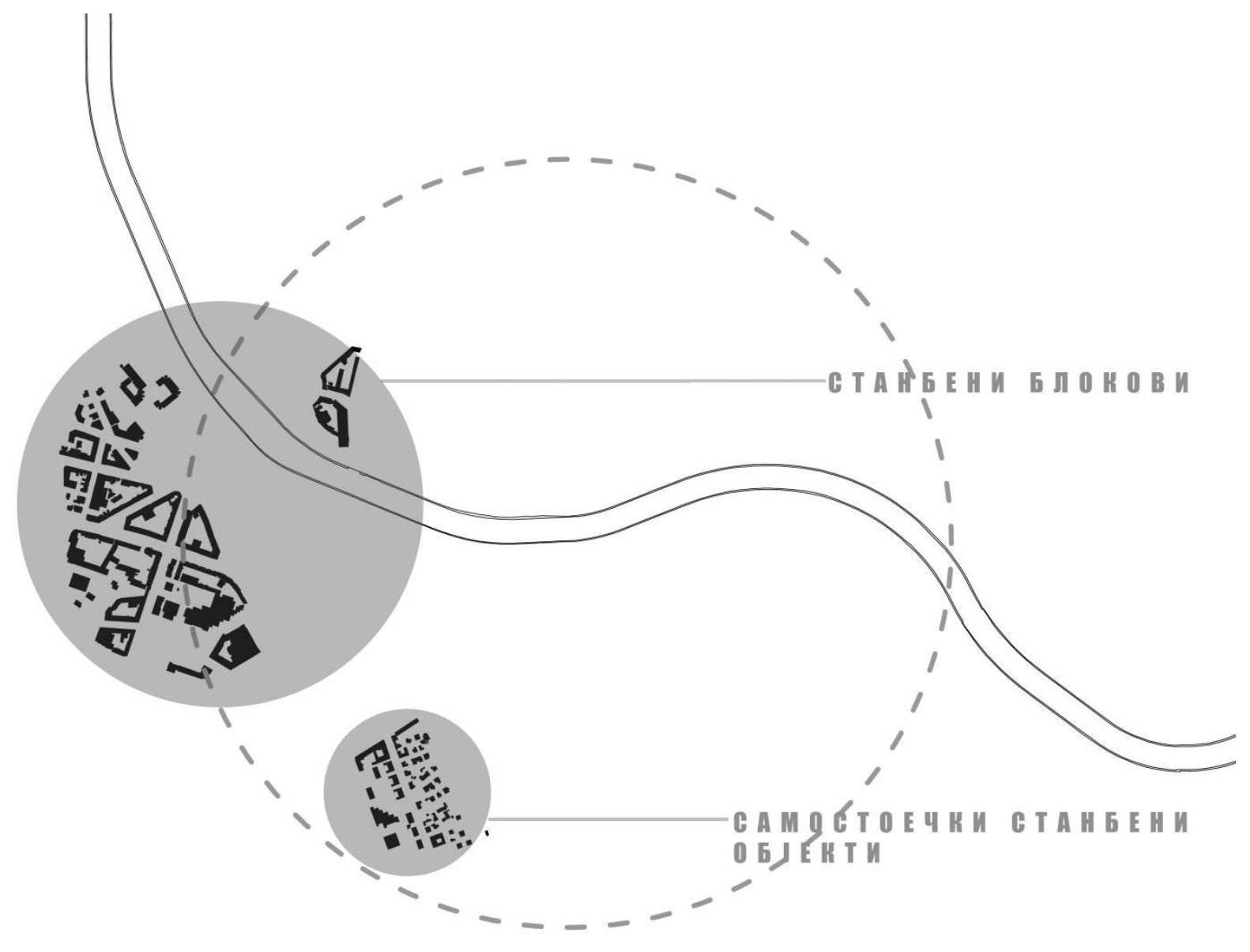

Сл. 9 Скопје - урбан слој - прва половина на XX век 


\section{3. Урбан слој - 60-ти години на XX век}

Во педесетите години на XX век, започнува еден нов период на урбаното планирање. Во тој период, односно во 1947 година, на група архитекти од Чехословачка на чело со Л.Кубеш, доверена им е изработка на регулационен план за Скопје. После серија на анализи, дискусии, снимања, изработен е Генералниот регулационен план за Скопје. Според Проф. М.Бакалчев, на просторно ниво, планираната прогресивна екстензија на градот, означува премин од централен, радијален тип кон линеарен град, темелен на една битна промена на просторното искуство со губење на асоцијативните особини на изграденото. На програмско ниво, планот воведува една нова, експлицитна, функционалистичка доктрина во дефинирањето на урбаното поле. Се промовира функционалниот град, изведен од доктрината на СІАМ, Атинската повелба (CIAM IV 1993) и методите на поделба на градот на четири категории, принципиелни функции: домување, рекреација, работа и транспорт.

Станбената зона опфаќа најголема градска површина и тоа 1.116 ха, или 23,61\% од вкупниот градежен реон, во три поголеми целини на запад, север и југоисток. Токму фрагментот на населбата Пролет е еден дел од зоната за домување во југоисточниот дел на Скопје. Овој фррагмент има типична конфигурација според концептот на модерната и е обликуван со отворени блокови со слободностоечки станбени објекти, обезбедени придружни содржини (снабдување, спорт и сл.), сепариран сообраќај (обезбеден само пешачки , а не и колски пристап до објектите) и многу блоковско зеленило. 


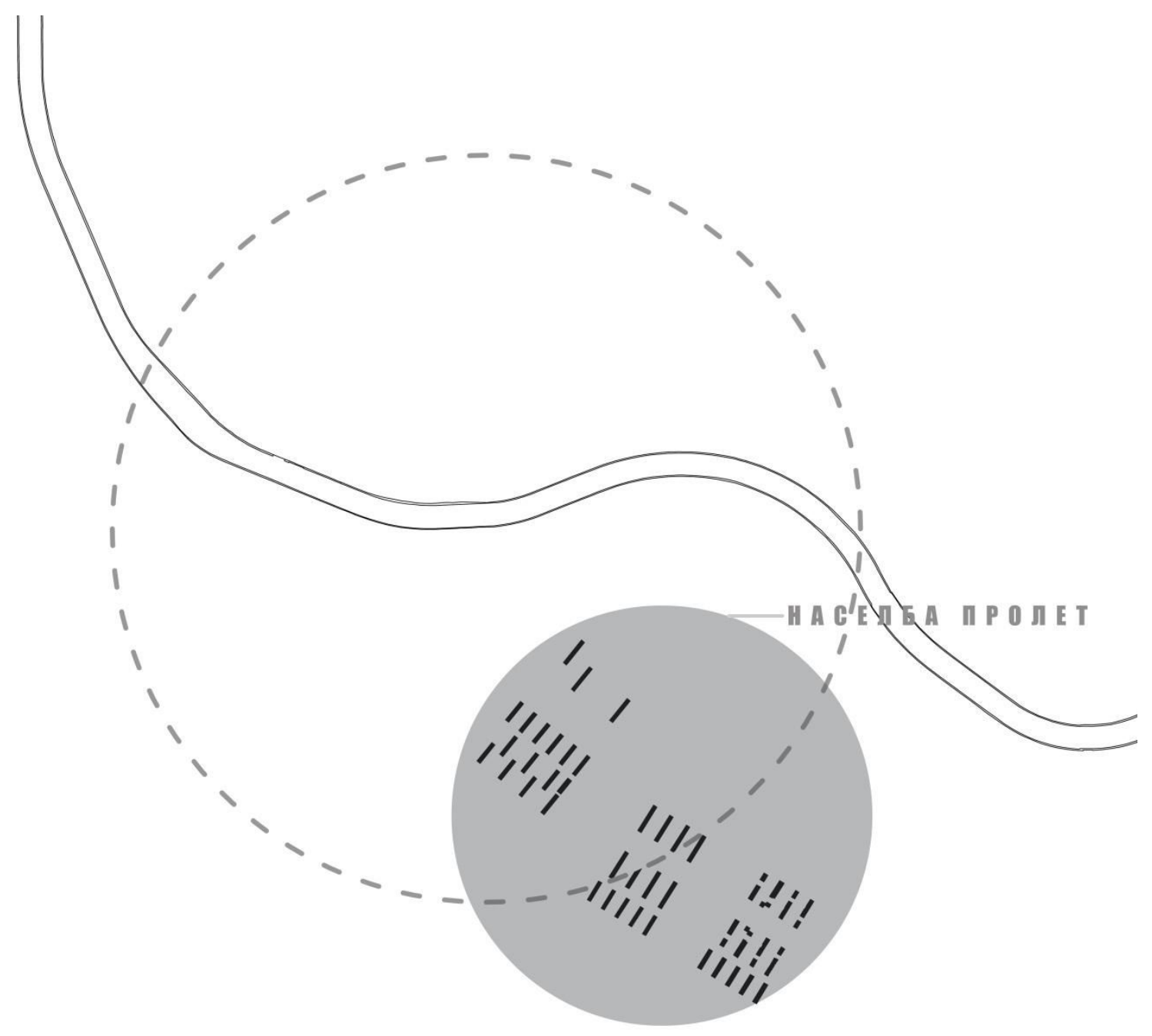

Сл. 10 Скопје - урбан слој - 60-ти години на XX век 


\section{4. Урбан слој - втора половина на XX век}

Скопје како град, после катастрофралниот земјотрес во 1963, драстично го менува својот лик, па затоа историјата во тој период е историја на дефинирање на проект на урбана обнова на градот. Се барало еден глобален модел на обнова на оштетен град, во кои биле вклучени низа локални, национални и интернационални фрактори. Обединетите Нации, употребија, специјален фронд, како помош во подготовката на генералниот план за Скопје. Адолф Циборовски е номиниран за проектен менаџер (1964) и избрани се две фирми од Варшава и Атина за да го изработат дефинитивниот урбанистички проект во соработка со Заводот за урбанизам на градот Скопје. Центарот на градот е исклучен од генералниот план, за него е распишан интернационален конкурс. Осум архитектонско-урбанистички тимови се селектирани за партиципација во конкурсот за десринирање на моделот за реконструкција на градот. Селектирани се четири југословенски фрирми и четири светски фрирми. Интернационалното жири со претседателство на Ернест Ваисман ја доделија наградата на К.Танге (60\%) и на Р.Мишевиќ, Ф.Вензлер (40\%). Втората фраза, предвидуваше дефинирање на едене урбан проект (“деветтиот проект”) темел на сите идеи кои се вредни во реконструкцијата на градот и сугестиите на жирито. По завршувањето на ова ниво, парциално прифаќање на концептуалниот план, проектот продолжи во третата фаза, деталирање низ архитектонските планови. Така во рамките на специјалниот фонд на $\mathrm{OH}$, кој се однесува на урбаното планирање, израборени се серија на детални планови на архитектонско-урбано ниво на различните теми на урбаниот проект на централното подрачје. 
Теоретскиот концепт на К.Танге тргнува од ревизијата на функционалистичкиот пристап. Тој наведува: “Гледајќи назад, на мојот пристап кон архитектурата и урбаниот дизајн, пронајдов дека мојот најран пристап беше функционалистички, но многу рано, проблемите ги надминаа границите на функционалистичкото појавување... одевме кон проблеми кои се чинеа невозможно да се решат, единствено преку функционалистичкиот пристап. Пронајдовме дека дополнување на фрунццонирањето (“functioning”), треба да ја додадеме просторната структура. Почнавме да веруваме дека развојот на процесот на структурирањето (“structuring”), е базична тема на урбаниот дизајн.

Според истражувањата на Проф. М.Бакалчев, урбаниот дизајн на централното градско подрачје, се темели на два принципиелни елементи: “Градската порта” и “Градскиот sид". Овие два елементи беа предмет на моделирање на процесот на конкретизација на урбаниот дизајн во тите фрази, но нивната просторна, програмска, семантичка функција остана непроменета. Градската порта во физичка и симболичка смисла е вовед кон градот, појдовна точка на новата оска (исток - запад). Од друга страна, Градскиот sид треба да ги собира резиденцијалните содржини, во една концентрична конфигурација која го опишува централното подрачје.

Денешната фрагментарна основа на Скопје, содржи одредени делови од овој урбанистички план, кои како такви функционираат, иако планот не е спроведен во целост.

Градскиот sид е еден од најзначајните градежни зафати по земјотресот. Композицијата “Градски sид” е составен дел на центарот на град Скопје. Објектите се лоцирани на десниот брег на реката Вардар, по обемот на бул. 
ЈНА, Јужниот булевар и бул. Кочо Рацин. Композицијата се состои од станбени блокови со катност од П+6 ката и кули од П+12 ката. Станбените објекти со својата поставеност офрормуваат големи зелени површини и површини за сместување на детски градинки, училишта, детски игралишта, надвор од сообраќајните движења. Во рамки на зафатените простори планирани се и гаражи во подрумите на станбените објекти. ${ }^{7}$

Транспортниот центар во фрункционална смисла се користи како целина во која се разменуваат различните типови на движења во градот. Тој ги вклучува следните фрункционални елементи: Централна железничка станица, Меѓуградски автобуски терминал, Градски автобуски трминал, Пошта, Царинска канцеларија, авионско претставништво.

Во овој период се реализираат и јавните објекти и објектите од општествен стандард, пеку распишување на јавни конкурси. Според овој принцип се врши проектирањето и изградбата на најважните икомплексните градски јавни објекти и простори како: Универзитетскиот кампус, Градскиот трговски центарГТЦ, Комплексот Банки, Македонската опера и балет - МОБ итн.

\footnotetext{
${ }^{7}$ Пенчиќ, Дивна, Влијанието на урбанистичките планови врз дисконтинуираната просторна транзиција на градот Скопје во двесеттиот век, необјавена докторска дисертација, Архитектонски факултет Скопје, Универзитет СВ. Кирил и Методиј, Скопје, 2011, стр.16-120
} 


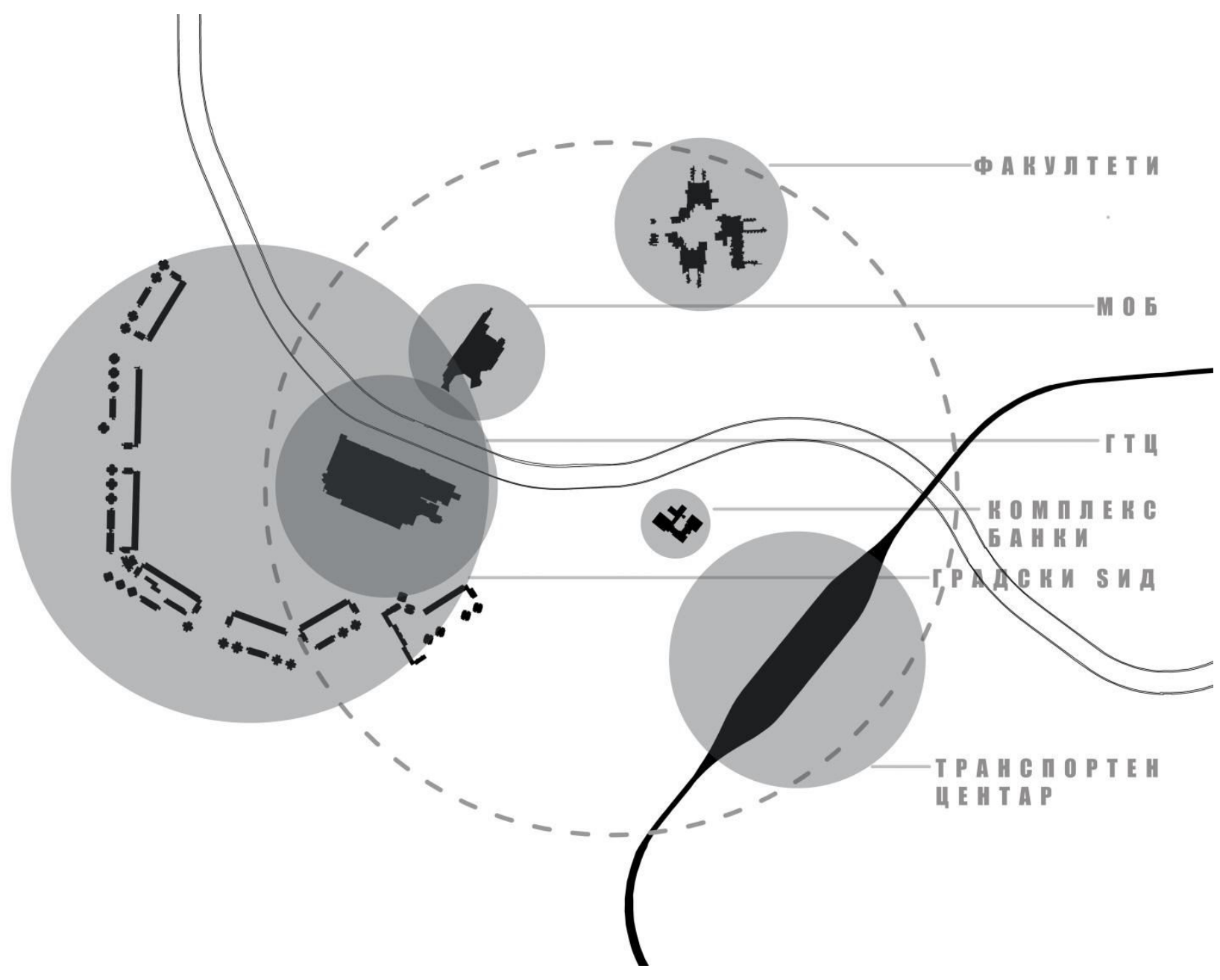

Сл. 11 Скопје - урбан слој - втора половина XX век 


\section{3. Надградувајќи го Ново маало, Скопје XXI век}

Следејки ја историјата на градот на XX век, ја препознаваме неговата фрагментирана состојба. Прашањето кое се поставува е како да реагираме на специфричните фрагменти на градот. Овој проект се насочува кон Ново маало, ја истражува неговата социална, просторна структура со цел да предложи тактика за осовременување на неговата станбена текстура.

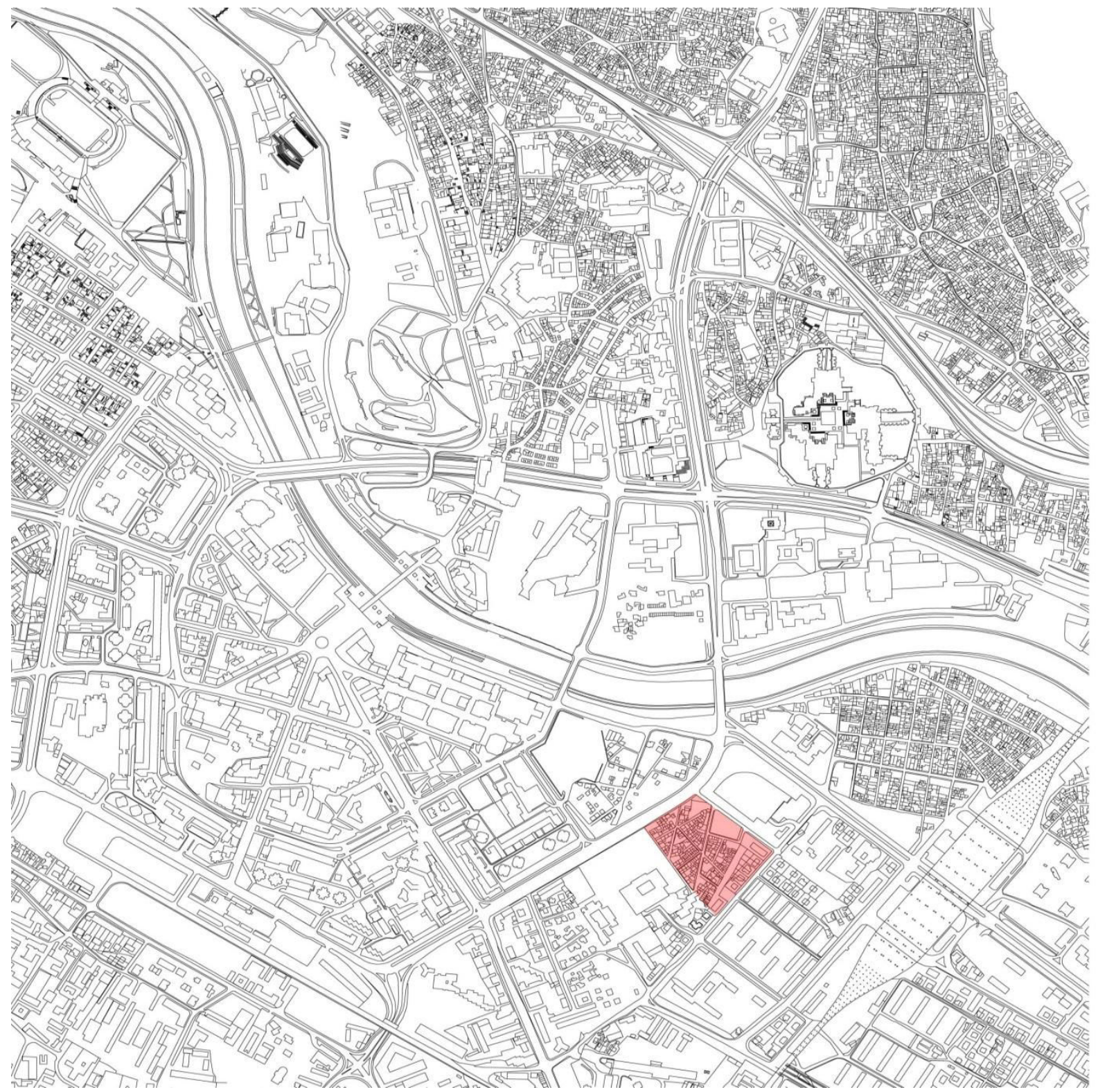

Сл. 12 Скопје - ситуација XXI век 


\section{1. Квалитети на Ново маало}

Што ги карактеризира здравите заедници? Тие се полни со живот, интимни и разновидни. Тие ја комбинираат човекомерноста со критичната маса и густината, нудејќи истовремено индивидуална слобода и социјална кохерентност. Тие еволутивно растат. Тие се еластични.

Како можат овие квалитети да се опишат, дестилираат и да се трансформираат во конкретни параметри?

Човековите колонизации низ светот заеднички поседуваат одредени квалитети со чија комбинација се креираат еминентни заедници погодни за живот. Термините како 'индивидуалност', ‘човекомерност', ‘колективност’ и 'различност' се често кажувани како карактеристики на овие места, но што всушност овие термини значат?

Овој дел од анализата на Ново Маало е обид да се соберат, дефинираат и категоризираат овие квалитети кои ги поседува ова Скопско маало по модел превземен од книгата "The vertical village" од MVRDV. Ова е квалитативна - не квантитативна - анализа, која има за цел да ги прикаже многуте субјективни аспекти на јавниот и приватниот простор, детерминирани според слободна проценка. Единаесет клучни квалитети во Ново Маало ќе бидат прикажани и секој од нив ке биде елебориран со слики од самото маало кои коренспондираат со дадената карактеристика. ${ }^{8}$

\footnotetext{
${ }^{8}$ MVRDV and The Why Factory, The Vertical Village, Netherland, 2012
} 
- Густина

Маалото е густо, креирајќи урбана енергија, живост и интензитет кои произлегуваат од квантитативната програма, бројот на жители така што жителите се принудени да живеат на мала површина. Преку оптимизиран дизајн и генерално социјално разгледување, негативните аспекти живеејќи во густо населени заедници можат да ce неутрализираат преку можностите кои тој простор ги нуди.

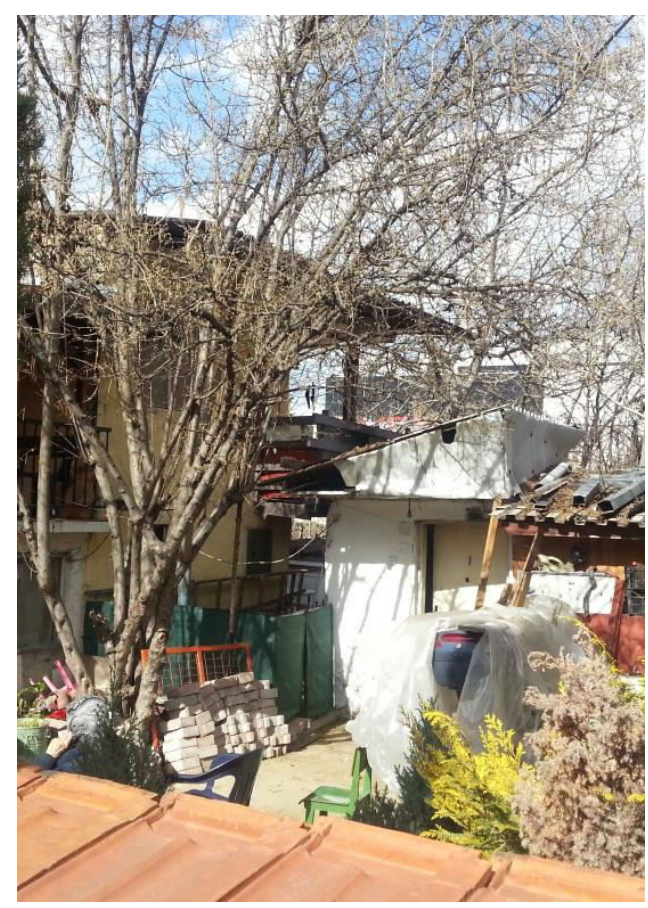

- Индивидуалност

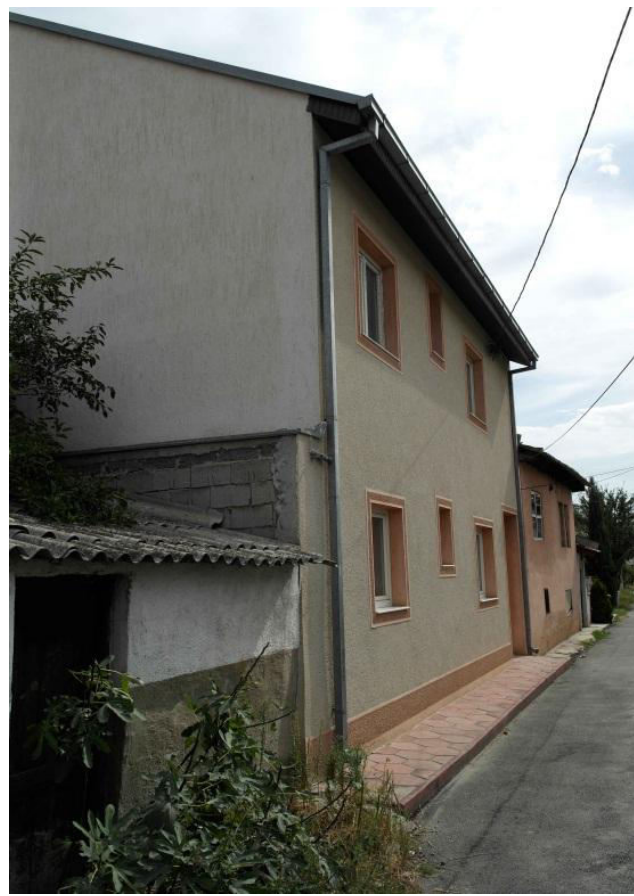

Маалото поседува индивидуалност во својата тек стура, дозволувајќи им на просторите да бидат уникатни, приватни, воедно креирајќи изолирани дискретни контрапунктови за долгите погледи на колективното живеење. Индивидуалноста се базира на слободата на изразувањето преку човековиот простор за живеење. 
Маалото поседува критична маса, иако е во процес на раселување на жителите заради низа рестрикции за градба, сепак тоа има доволно жители за да имаат самоодржлив социјален моментум, задржувајќи и зајакнувајќи ги своите позитивни аспекти со тек на време. Индивидуалците се привлечени заедно од оваа сила, создавајќи чувство на урбаност како еден фринален проект позначаен од сумата на

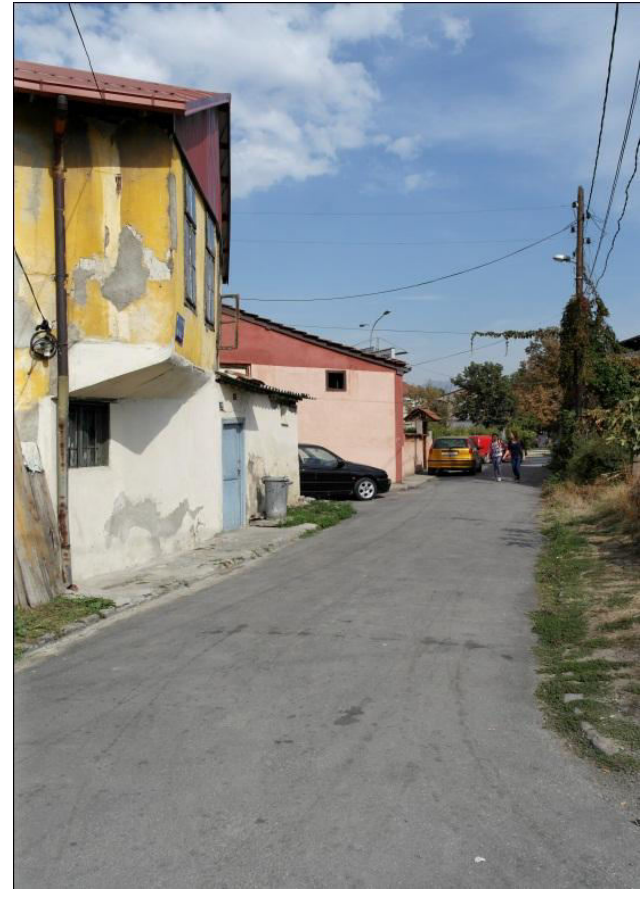
неговите поединечни делови. Критичната маса е постигната тогаш кога одреден број на луѓе ке достигне одреден праг кој генерира густина и колективност.

- Флексибилност

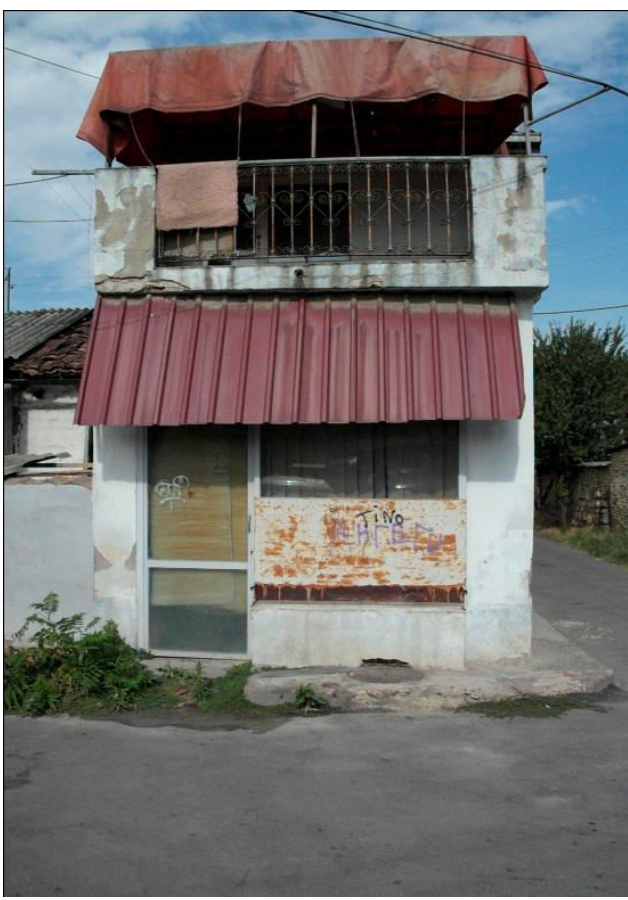

Маалото е фрлексибилно, тоа ја прифаќа неизбежноста на менување на потребите и желбите со текот на времето. Флексибилните заедници како што е случајот со Ново маало се екстензибилни и адаптабилни, што им дозволува да бидат подготвени за непосредните потреби, користјќи ги ресурсите достапни како прототипови за идните 
можности. Флексибилноста може да се измери преку способноста за модификација односно промена на опкрожувањето, способност овозможена од сопствеништвото и отсуство на плнерски или регулаторни контроли.

- Колективност

Маалото, односно заедницата е колективна; таа нуди чувство на припадност, дел од сигурна и взаемно поддржана група, која ги споделува начинот на живот, амбициите, карактерите и квалитетите, поврзани меѓусебно преку густата социјална структура. Просторно, жителите во маалото се организираат и групираат околу полу-јавен заеднички простор, во кој се социјализраат истите. Колективноста може да се измери

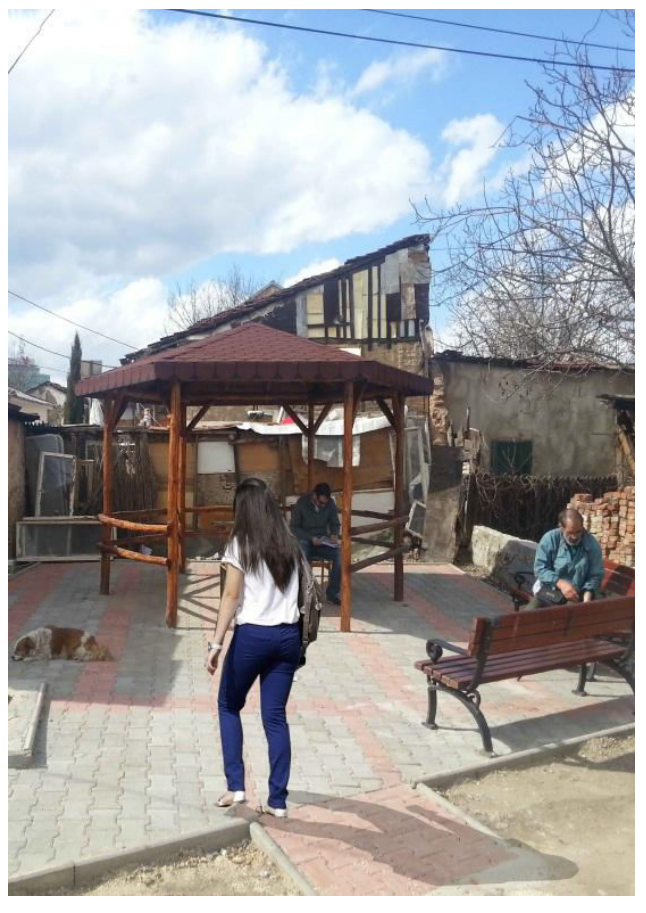
преку мксот на приватен и јавен простор и присуството на заеднички програмски содржини. 


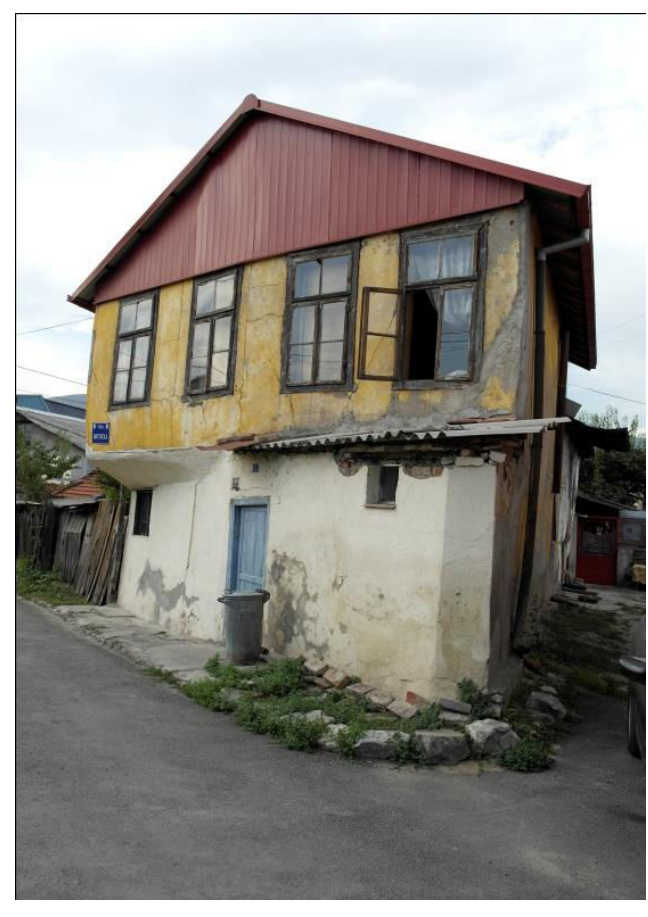

Маалото еволуира. Неговиот просечен карактер е детерминиран од еден растечки процес на адаптација и оптимизација во локални услови. Неговиот развиток е органски и се развива во вертикала, рефрлектирајќи ги променливите потреби, желби и навики на жителите кои ја обликуваат средината во која што живеат. Еволутивниот раст може да биде измерен преку континуирано инвестирање или развивање во самата област.

- Диверзитет

Маалото е различно. Тие ги прегрнуваат екцентричноста и плуралноста, префферирајќи комплексност јукстапозицијата во однос на монотонијата и повторувањето. Во различните заедници жителите ги прифаќаат меѓусебните култури и желби, заеднички придонесувајќи кон слоевита и збогатена целовитост. Диверзитетот може да биде измерен преку процентот на застапеност на различните

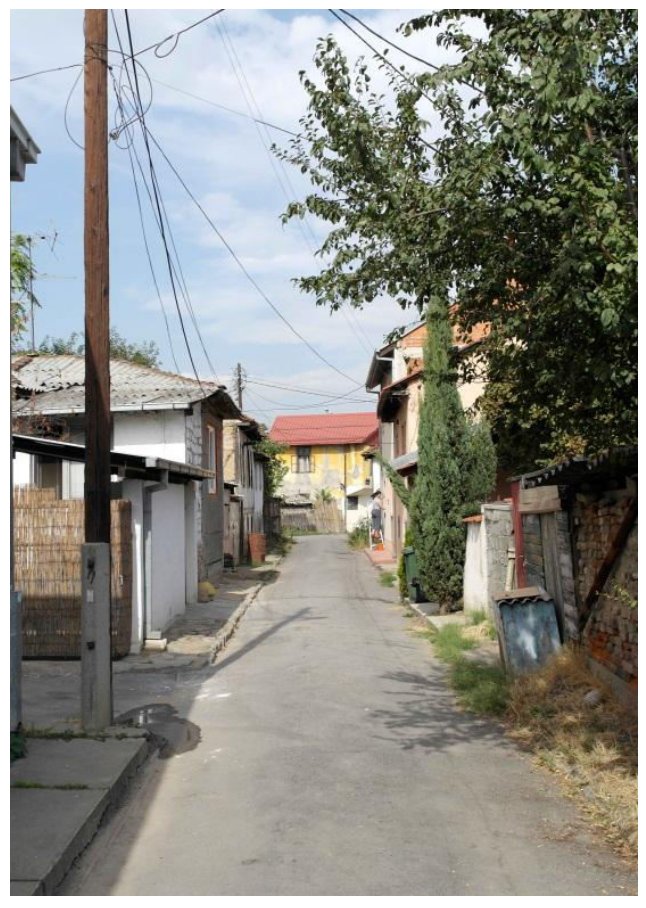
програми, стилови или размери во определена област. 


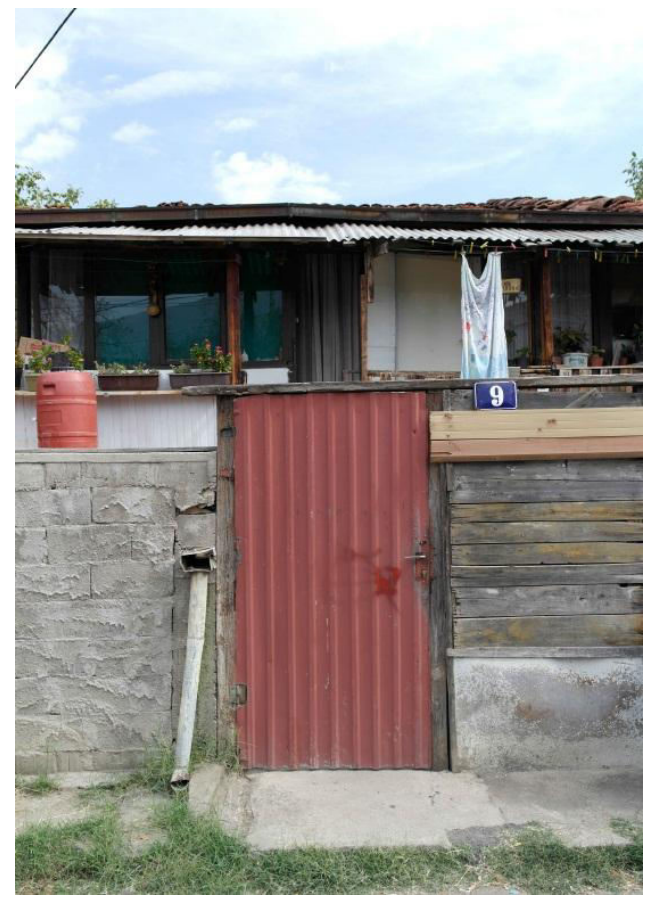

Маалото е човекомерно, нудејќи пропорционална, материјална и просторна интима која е соодветна за престој и организација на секојдневието. Човекомерните простори се простори на социјално опкружување, темели на здрава животна сфрера. Дали просторот е човекомерен или не зависи од неговите пропорции: просторите кои имаат мала висина, кои се стеснети и кои се модулирани може да бидат сметани како човекомерни.

- Јавност

Маалото е јавно, тоа е слободно и отворено за посетители, нудејќи простор за социјални активности, колективни дебати, дури и за несогласувања. Добро осмислениот јавен простор ја содржи моќта да ги испровоцира демократските вредности во едно отворено општество, дури и пред лицето на помалку толерантните политички сфери. Јавноста наједноставно може да биде измерена како дел од просторот наменет за заедничките функции, споредено со приватните функции (ова ја нагласува важноста на социјалните акивности во креирањето на квалитетот на јавното мислење). 


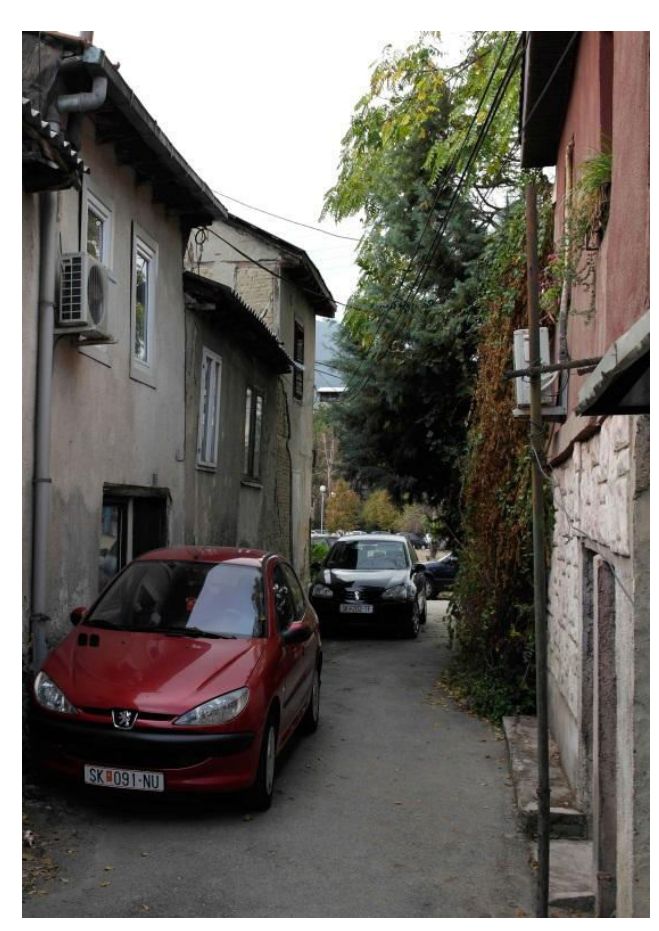

Маалото е неформално, тоа ги прифаќа спонтаните и импровизираните додатоци и модификации направени од страна на жителите. Овие модификации се неопходно релаксирани и мали според размерот, рефрлектирајќи ги желбите на индивидуите, кои функционираат внатре - како водечки план на еден принцип. Неформалноста може да биде измерена преку присуството на индивидуални и спонтани дополнувања или

на add-hoc простори.

\section{- Идентитет}

Секоја заедница има идентитет: нудејќи кохерентна рефлексија на карактеристиките на жителите во Ново маало, нивните навики, култура, програмите и животниот стил, преку определена фризичка фрорма. Овој колективен идентитет ја изразува взаемната социјална гордост базирана на идегритетот, препознатлива како од жителите, така и од посетителите. Силата на индентитетот на едно место може да се измери преку

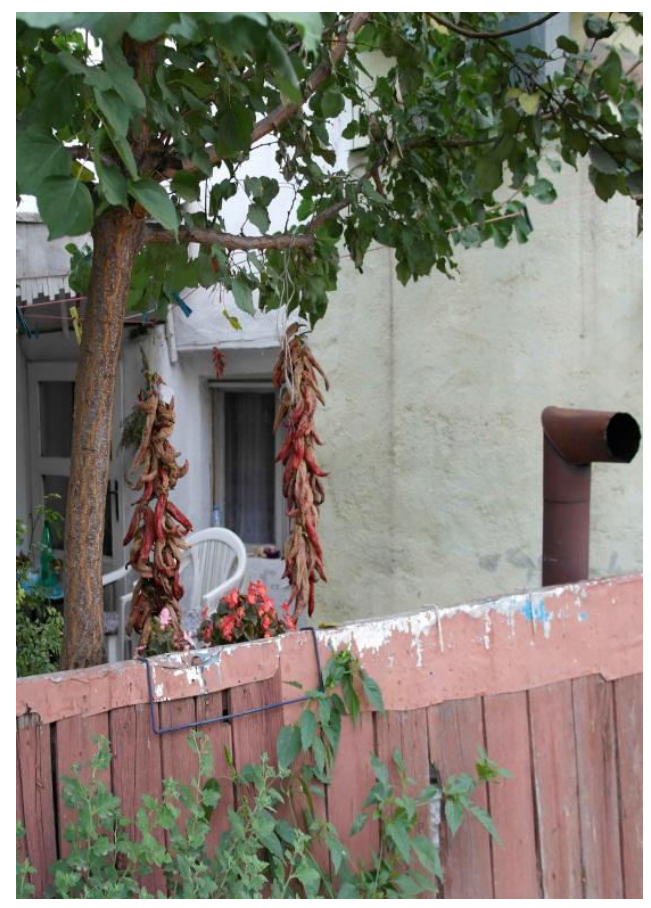
неговата просечна визуелна кохеренција и препознатливост. 


\section{2. Процес на надградување}

Трансформацијата на Ново маало е замислена така да се добие нова колективна форма која ќе биде во коегзистенција со постојната фризичка структура на маалото, како и квалитативно да го надгради, истакнувајќи ги претходно елаборираните квалитети кои ги поседува.

Анализирајќи ја дадената програма и однапред поставената хипотеза, го поставувам концептот и целта на овој проект со што завземам став да се задржи постојната состојба на Ново маало. Откривајќи и истражувајќи ги проблемите на ова маало, се обидов истите да ги претставам повеќе како предизвици со кои се среќава урбаното ткиво, кое е постаро од 100 години и останало такво какво што било и во XXI век, отколку како пречка во проектирањето на новата програма. Главната цел е да се создадат нови капацитети за домување, како и нови јавни простори кои не само што ќе му служат на ова маало, туку ќе бидат и нови конектори на различни делови од Скопје, поврзувајќ различни програми и јавни содржини. Поврзувањето, врската и конекцијата се едни од клучните зборови како формално така и концептуално.

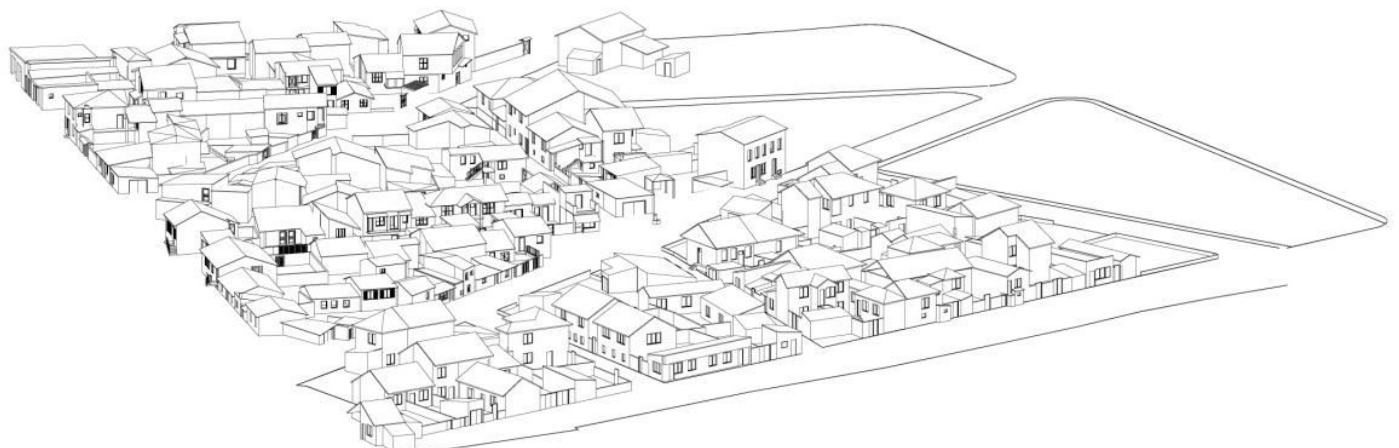

Сл. 13 Аксонометрија на постојна состојба на Ново маало, Скопје 
Атмосфрерата на стариот град сеуште не е изгубена во Ново маало, покрај распаднатите фрасади се крие друга вистина на просторот, една човекомерност, блискост и носталгија. Исто така и 'изолација' е важен поим кој се наметнува, можеби позитивен, замајќи ја во предвид урбанизацијата и наглото градење кое му се случува на Скопје. Концептот и пристапот може да се копира и повторува на други делови во Скопје, најмногу од аспект на поврзување на зони од јавен карактер, рекреација, јавни отворени површини... па зашто да не кејот на реката Вардар со Водно...

Надгрдувањето како основа тактика при фрормирањето на новата урбана струкура, како и на новите модели на домување, потекнува од досегашниот развиток на Ново маало. Иако постоеле планови за нова урбанизација на маалото, тие никогаш не се претвориле во фризичка структура, маалото еволуирало и се ширело спонтано и стихијно, но само во неговите постојни рамки. Се надградувало, доградувало, оградувало но никогаш не постигнало драстично да се зголеми капацитетот за домување. Со ваквиот развиток на некој начин се постигнува квалитет со тоа што новосоздадените просторни елементи остануваат во константен контакт и сооднос со дотогашната структура.

Уличната мрежа во Ново маало е неправилна, со прави, но неправилно поставени тесни улици. Токму уличниот модел е една од водечките теми во новата фрорма. Во предложениот проект, сообраќајното решение е променето, ce co цел поголема проточност на колскиот сообраќај. Улиците во внатрешноста на маалото остануваат такви какви што се - колско- пешачки, додека по периметарот на маалото, односно јужно од него, според новиот детален урбанистички план се предвидува булевар. Западно, се предвидува 
новопроектирана колска улица која би ги поврзувала постоечкиот булевар “Кочо Рацин” со новопроектираниот.

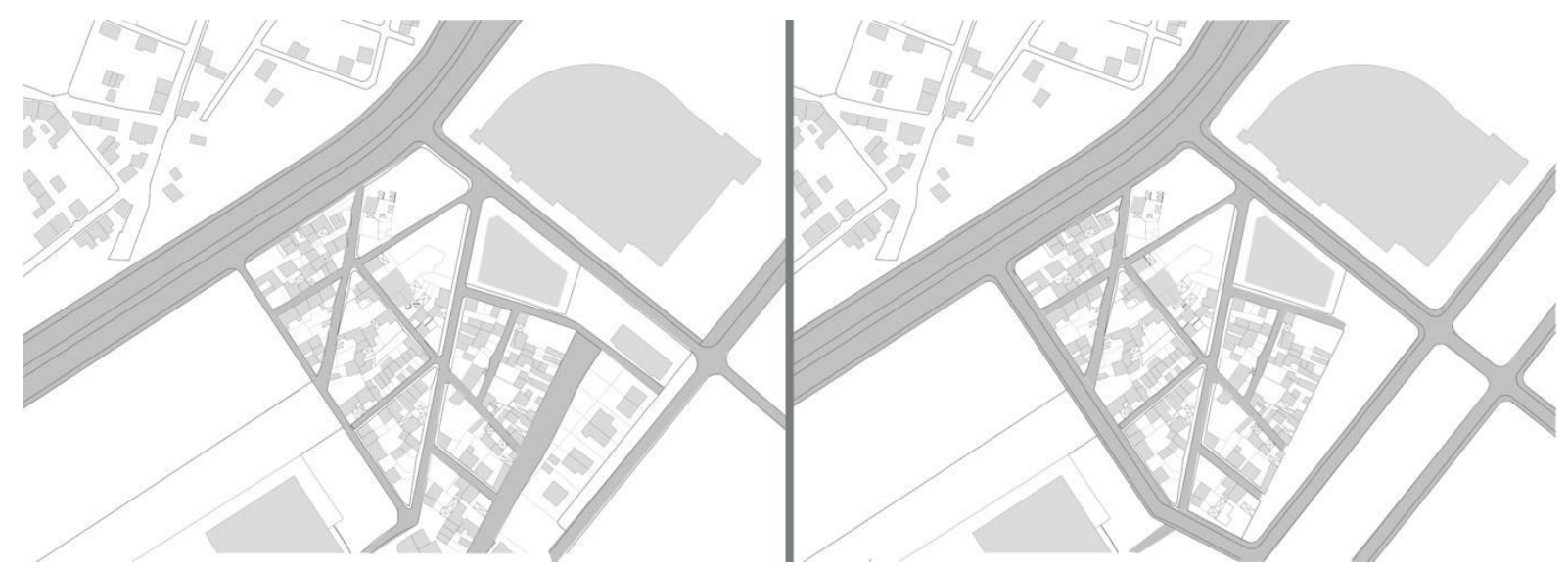

Сл. 14 Улична мрежа-Ново маало; постојна/новопроектирана

Новата структура предвидува линиски мостовски структури кои се поставуваат над изграденото ткиво долж улиците во Ново Маало. Мостовите допираат на површината со ритмично поставени носиви елементи - столбови, создавајќи тремови. Позицијата на мостовите произлегува од основниот уличен модел на Ново маало, поставени се покрај 3 улици кои меѓусебно се сечат, од кои две во “центарот” на маалото. Два од мостовите претставуваат подлога за домување, а третиот, највисокиот, претставува пешачки и велосипедски мост, конектор на кејот на реката Вардар со Ново маало и новопроектираниот јавен отворен простор кој е вдлабнат.

Проектот предвидува две вертикали-кули кои програмски и фрормално се разликуваат, воедно му даваат еден нов квалитет на маалото. Едната е наменета како паркинг автоматизирана кула, каде што на самиот врв се појавува резервоар за атмосферска вода, додека втората е наменета за домување. 


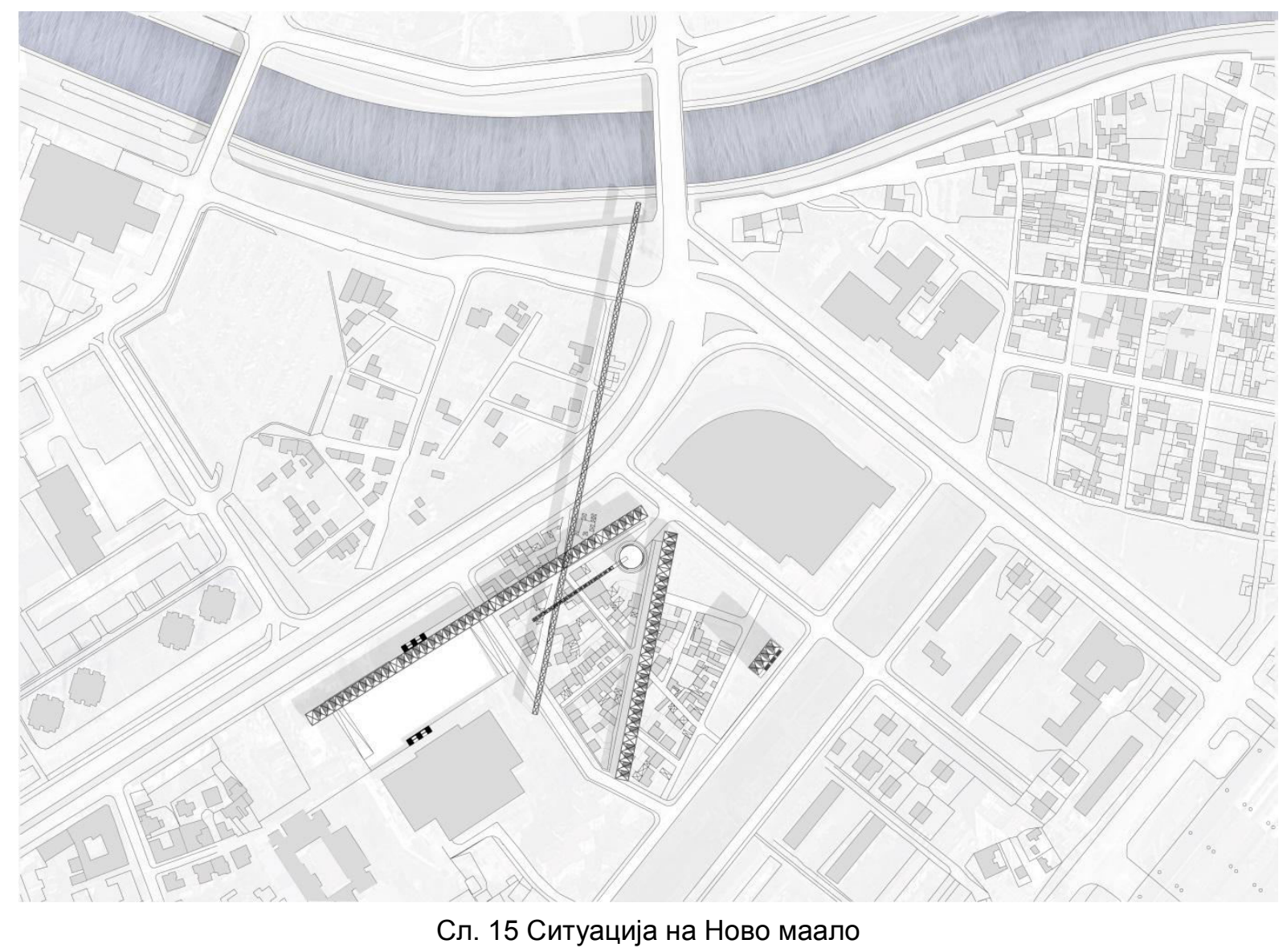

\subsection{1. Станбени мостови}

Станбените мостови се позиционирани над улиците "Светозар Марковиќ” и слепата улица која е паралелна на булеварот “Кочо Рацин”. Широки се 9 метри и подолжно се поделени на зона за домување и зона за пристап кон единиците. Подигнати се над постојната текстура на Ново маало 12 метри и носени од челични кутијасти столбови (30х30см) кои ритмично се повторуваат на секои 12 метри. Поради големата висина на самите столбови, тие се витки и постои потреба на одредено растојание тие да се укрутат со попречни прачки. Тоа укрутување се случува токму онаму каде што се поставени комуникациските јадра. Тие се поставувани тамо каде што тоа е возможно, односно на 
слободните парцели во маалото. Во модулот од 12 метри поставени се две станбени единици, односно за секоја по 6 метри од кои 4.40 метри е самиот објект, додека просторот што останува е наменет за пристап кон истата. Целата конструкција е составена од челични носачи кои се најпогодни за еден ваков тип на структура. Освен од столбовите, мостовската линиска конструкција е носена од решеткаст челичен носач кој е висок 9 метри, димензиониран соодветно за еден ваков вид на структура. Носечката греда кај овој носач е со дебелина од 80 цм каде што на растојание од 6 метри, попречно се поставувани секундарни греди. Освен конструктивна улуга, тие дополнително го одредуваат просторот наменет за една станбена единица. Висината на челичната решетка всушност ја дефинира и максималната висина на единиците. Со оглед на тоа дека единиците се секогаш исти по димензија и ритмично се повторуваат долж мостот се добива еден рамномерен план кој варира само во висината и во поврзувањето на самите објекти што зависи од самите сопственици на објектите. Домувањето во овие мостовски структури има еден динамичен и фрлексибилен карактер, но од друга страна еден одреден и строго десиниран модул кој може да се шири колку тоа да е потребно.

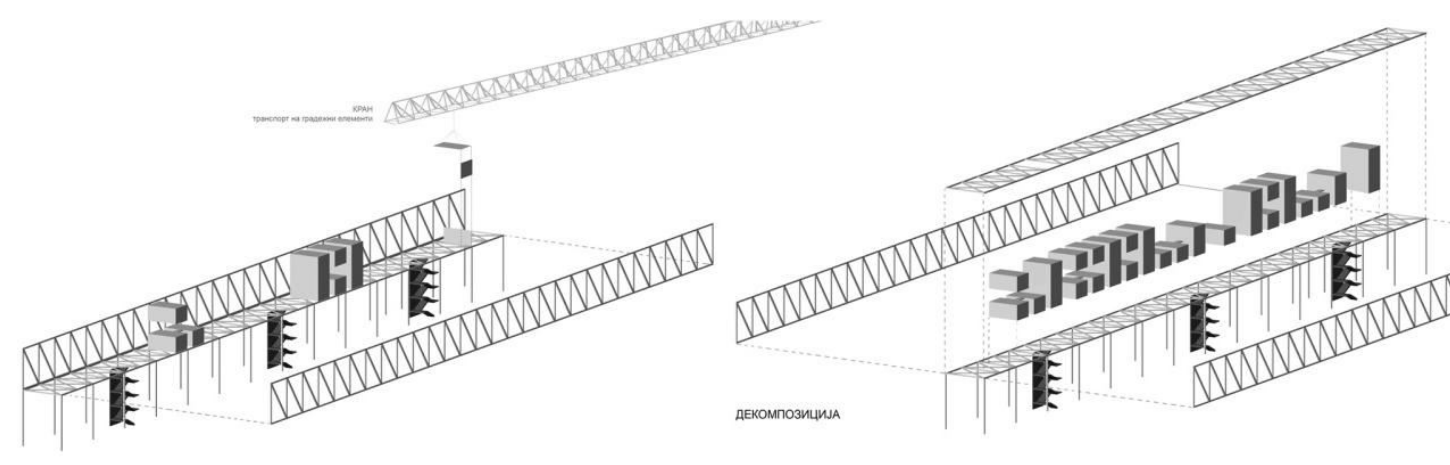

Сл. 16 Декомпозиција на станбен мост 


\subsection{2. Станбени единици}

Станбените единици претставуваат еквивалент на куќа во Ново маало. По својот габарит, единиците ги поддржуваат и ги надополнуваат веќе споменатите квалитети во маалото. Тие имаат унифицирана димензија во основата, односно основата е правоаголна со димензии 4.40м на 6.50м, односно бруто површина од $28.6 \mathrm{~m}^{2}$ (површина во основа). Се равиваат во максимум 3 нивоа, односно П+2, со максимална висина од 8.15 м. Конструкцијата е предвидена од челични кутијасти столбови (15х15), кои ги носат меѓукатните конструкции. Единицата е формирана од префабрикувани панели, кои се вметнуваат во мостовската структура, фформирајќи нов, уникатен простор за живеење. Програмски единицата е концепирана така што секогаш дневните простории се наоѓаат на најгорното ниво, поради потребата од поголема катна висина, додека собите за спиење се на долните нивои. Во основа се забележува едно кружно движење, каде што скалите се минимални и секогаш ја имаат истата позиција. Доколку семејтвото е повеќечлено, односно се јави потреба за простор плус, единиците се фрлексибилни, така што овозможуват присоединување на две единици за максимум 8 члена. Предвидени се 5 основни типа на единици, кои со нивно комбинирање се добиваат дополнителни 4 единици. Различните единици нудат модели на интегрирано домување за луѓе со различни животни стилови.

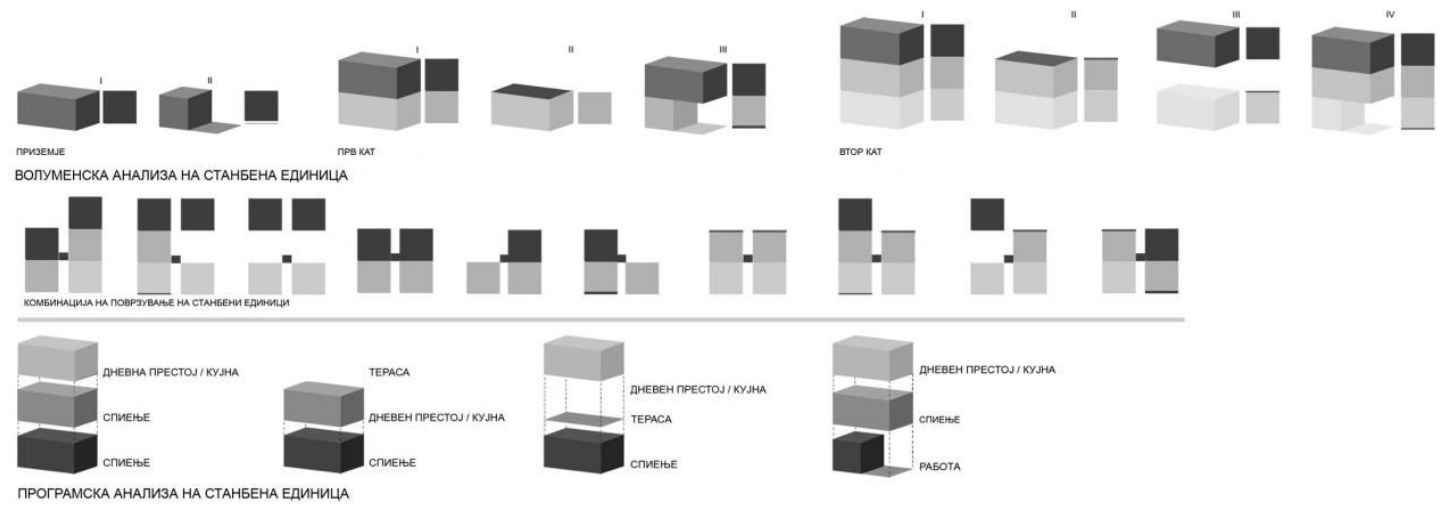



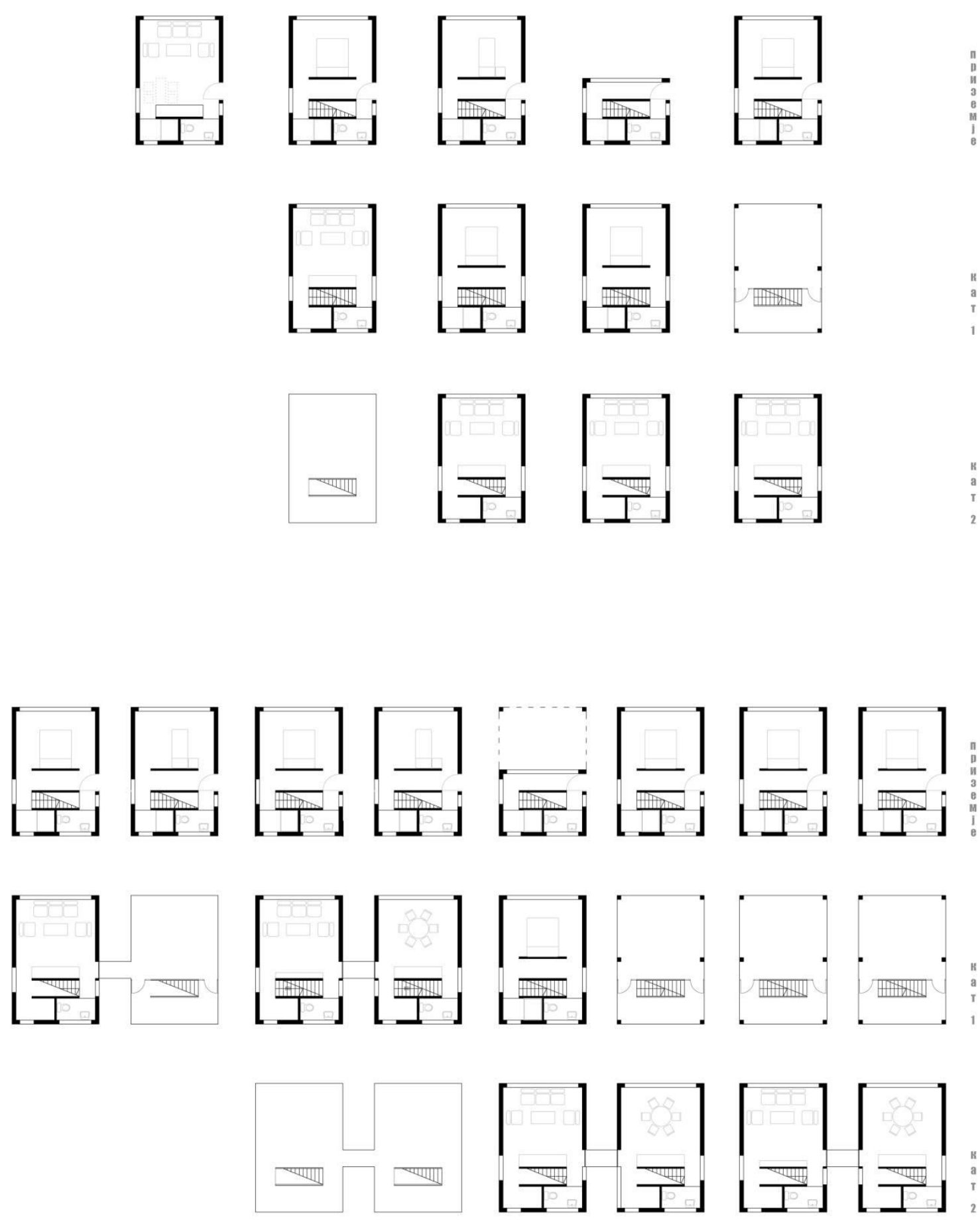

Сл. 17 Каталог на станбени единици 


\subsection{3. Пешачка и велосипедска мост/патека - конектор на кејот на реката Вардар со Ново Маало}

Пешачкиот мост е еден вид конектор на кејот на реката Вардар со Ново Маало и новопроектираниот отворен јавен простор. Неговата позиција исто така е одредена од уличната матрица на Ново маало, потточно од улицата Битолска која своевремено продолжувала до самиот кеј на реката, но сега е прекината со булеварот “Кочо Рацин”. Со оваа предвидена структура се враќа една меморија од минатото, а воедно таа меморија постанува функционална со самото тоа што го поврзува кејот со овој дел од градот. Мостот се висок 20 метри, носен од челични кутиести столбови кои што се повторуваат на секои 24 метри. Мостот е широк 3.50 метри, каде што е поставена урбана опрема и најразлични пунктови со променлива намена. Предвидена е уште една секундарна програма, односно мали едници за привремено домување и работа. Тие единици се подигнати за 3 метри од површината на мостот и се развиваат на едно ниво. Примарната вертикална комуникација е предвидана со лифртови, димензионирани така да може да собере велосипед. Освен примарните спортско рекреативни активности кои веќе функционираат на кејот на реката Вардар, предвидена е и дополнителна активност - панорамски поглед на градот со балон. Оваа мостовска линиска структура ке му донесе на самиот град еден нов квалитет како во функционална и програмска така и во фризичка смисла.

На другиот крај на мостот, спротивно од кејот, се создава еден нов отворен јавен простор кој е вдлабнат 4 метри, кој воедно претставува своевидна критика на она што му се случува на Скопје. Овој простор е замислен како еден вид на плоштад кој со самото вдлабнување добива на интима и е "далеку" од 
градската бучава. Во овој отворен плоштад се пристапува преку рампи кои се поставени на двете пократки страни. Директен пристап е овозможен и до станбениот мост кој надвиснува над плоштадот. Со овој простор, не само жителите на Ново маало туку и сите граѓани добиваат нов квалитативен отворен простор кој можат да го уредуваат, менуваат, обликуваат и користат на разлен начин во зависност од нивните потреби.

\subsection{4. Паркинг кула}

Паркинг кулата е едноставна кружна челична структура со висина од 50 метри, која го надополнува овој проект како формално, така и функционално. Капацитетот на оваа паркинг автоматизирана кула е 60 возила што ги задоволува потребите на маалото. На секое ниво предвидени се пет паркинг места. Функционира со хидрауличен механизам, каде што возилото вертикано се транспортира со платформа, која се крева и се спушта. На најгорното ниво на кулата се наоѓa видиковец до кој се пристапува со скалишта кои кружат околу самата структура, или пак, со лифт кој се наоѓa во кранот кој е поставен непосредно до самата кула, кој воедно служи за транспорт на материјали при изградбата на целата нова урбана структура во Ново маало. На врвот на кулата се наоѓa резервоар за атмосферска вода, идеја која му дава дополнителен квалитет, воедно и самооддржливост на маалото. Капацитетот на резервоарот е со $2215000 \mathrm{~L} / 2215 \mathrm{~m}^{3}$. 


\subsection{5. Кула за домување}

Кулата за домување поставена е источно на територијата на Ново маало. Овој празен простор се формира со редефинирање на уличната мрежа според новиот Детален урбанистички план. Концепирана е според модел кој е превземен од станбените мостови, односно истите станбени единици кои формираат модул од 6 метри и кој што се развиваа по хоризонтала во линиските мостовски структури, во овој случај, се мултиплицира по вертикала. На секое ниво предвидени се по четири модули, односно четири станбени единици со максимална висина од 8.15 метри, всушност тоа претставува висината на едно ниво од кулата. Кулата е висока 68 метри, со слободно приземје. Комуникациите се јавуваат периферно по подолгата страна и совладуваат висина од 8.50 метри. Конструкцијата, следствено на онаа од мостовите, е челична, со кутијасти столбови со правоаголен пресек од 30х50см. Во кулата се предвидени 28 станбени единици од различен тип, за семејства со различен животен стил.

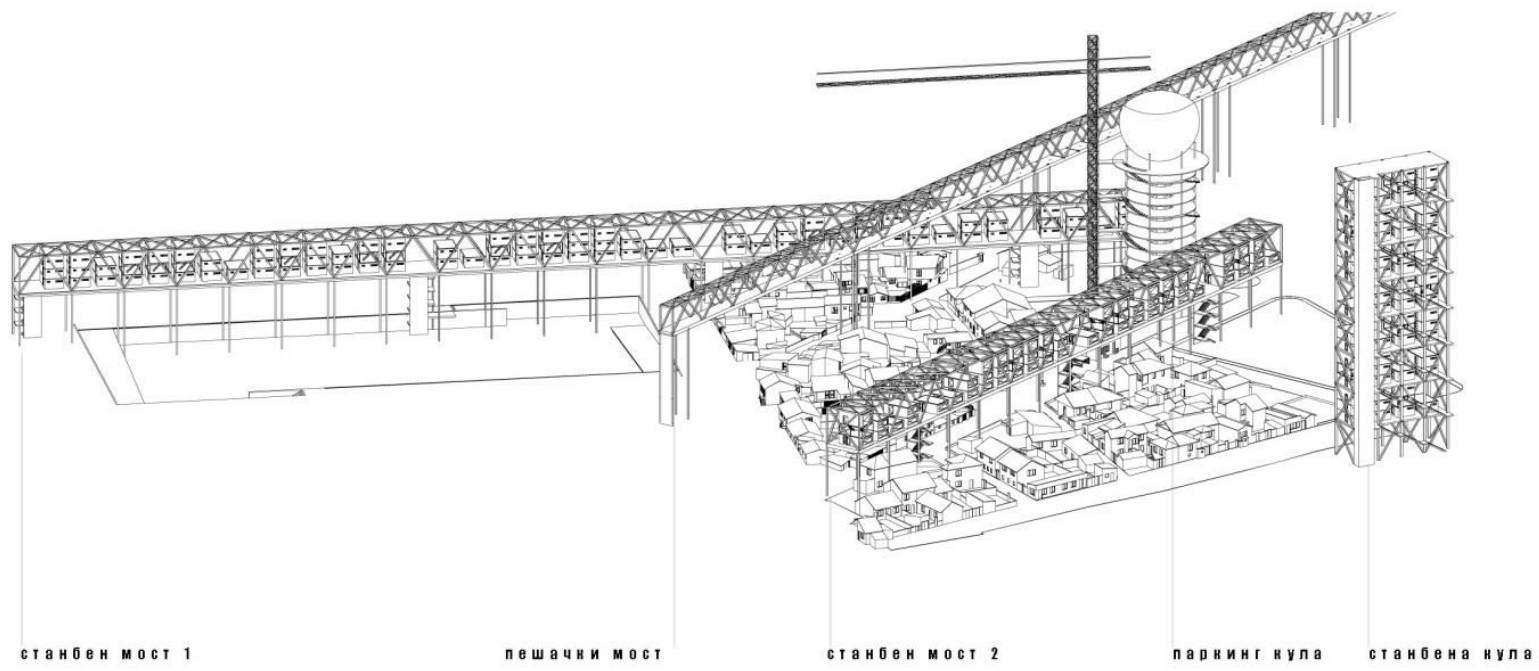

Сл. 18 Аксонометрија на предвидена состојба на Ново маало, Скопје 


\section{ЗАКЛУЧОК:}

Преку проектот тактики на трансформирање на станбената текстура, како и преку сеопфатно истражување и проектирање, дефиниран е еден начин на трансформација на една социјално маргинилизирана зона, која сеуште опстојува како таква во една градска средина. Проектот постигна едно зголемување на просторно програмскиот капацитет, но истовремено задржани се животните квалитети, кои беа претставени како клучни аспекти при проектирањето.

Проектот покажа дека надградувањето како тактика успешно функционира, нуди еден нов, современ начин на живот. Маалото кое постојано и стихијно поединечно се наслојува, надградува, доградува, сега би можело да го продолжи процесот, но на еден “колективен” начин.

Проектот преставува еден вид на експеримент, каде што преку линиски фрормации произлезени од уличниот модел на маалото, истото се надградува, воедно се шири по вертикала, но и се развива независно од ситната постоечка структура. Иако според новиот детален урбанистички план на подрачјето на Ново маало се предвидени блоковски структури и поништување на се што е постоечко, овој проект го негира таквиот начин на пристап и предлага една нова над-структура, која паралелно би фринкционирала со постојната. Мостовите, по својата природа служат како конектори, така и во овој проект постигнат е еден нов квалитет, поврзување на кејот на реката Вардар со маалото и новоформираниот јавен отворен простор, кој како една депресија, претставува критика на случувањата со јавните простори во Скопје. 
Современите стихијни, неконтролирани и неизвесни промени на нашата околина, ги доживуваме како закана. Тие претставуваат сериозна закана како за фризичкиот, така и за културниот и социјалниот модел на нашите заедници. Но токму овие промени треба да не стимулираат да ја ре-обмислиме нашата заедница, нашите живеалишта, нашите дворови.

Ваквиот пристап на трансформација на станбената текстура е наменет, првенствено да одговори на потребите на жителите на Ново маало, но може да послужи како модел кој би се имплементирал и во други слични, по структура, делови од градот. Со ваквиот пристап маалскиот живот повторно се актуелизира, нешто што блоковскиот напад на градовите го негира. Живеењето во куќа, а во центарот на градот не е само привилегија, но и негов социокултурен идентитет. Тоа всушност претставува еден од основните квалитети на вака реализираниот проект. 


\section{БИБЛИОГРАФИЈА:}

Бакалчев, Минас, Домување како урбан фррагмент. Необјавена докторска дисертација. Архитектонски фракултет Скопје. Универзитет Св. Кирил и Методиј, Скопје

Ekrem Akurgal, Ancient Civilizations and Ruins of Turkey, Net Turistiik Yayinlar A.S., 1990, pp. 47-62

Hertzberger, Herman, Lessons for students in architecture, 010 Publishers, Rotterdam, 1993

Hertzberger Herman, Collective Space, "Socijalna upotreba", in Articulations, 2002

Kaijima, M, Kuroda, J \& Tsukamoto, Y, Made in Tokyo, Kajima Institute Publishing Co. Ltd, Tokyo, 2006

Kolhaas, R, Delirious New York, The Monacelli Press, New York, 1994

Maki, F, Investigations in collective form. The school of Architecture, Washington University, St. Louis, 1964

MVRDV \& The Why Factory, The vertical village, Netherland, 2012

Пенчиќ, Дивна, Влијанието на урбанистичките планови врз дисконтинуираната просторна транзиција на градот Скопје во двесеттиот век, необјавена докторска дисертација, Архитектонски фракултет Скопје, Универзитет СВ. Кирил и Методиј, Скопје, 2011, стр.16-120

Smithson Alison and Peter, Cluster city, The Architectural Review, 1957

Smithson Alison and Peter, The Nature of Retreat, texts edited from lectures given at the University of California, Berkley, 1990

Venturi, R, Denise S B \& Izenour, S, Learning from Las Vegas: The Forgotten Symbolism of Architectural Form, MA: MIT Press, Cambridge, 1977

Wigley, Mark; Constant; Witte de With, Constant's New Babylon: The Hyper-architecture of Desire,010 Publishers, 2009 


\section{Илустрации}

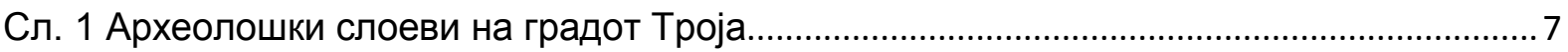

(http://en.wikipedia.org/wiki/File:Plan_Troy-Hisarlik-en.svg)

Сл. 2 Диоклецијанова палата - Сплит 8

(http://hr.wikipedia.org/wiki/Datoteka:SPLIT-Hebrard_overall_color_restitution.jpg)

Сл. 3 Просторна претстава за градот на Јона Фридман 9 (http://www.yonafriedman.nl/?page_id=78)

Сл. 4 Цртеж на концептот за Нов Вавилон .11

http://misterbros6.sslblindado.com/10/new-babylon-constant)

Сл. 5 Над-до-градба на објект во населба Мичурин .13

Сл. 6 Дијаграми за различните типови на надградување

Сл. 7 Фрагментирана основа - Скопје .18

Сл. 8 Скопје - урбан слој XIX-почеток на XX век 20

Сл. 9 Скопје - урбан слој - прва половина на XX век... .22

Сл. 10 Скопје - урбан слој - 60-ти години на XX век .24

Сл. 11 Скопје - урбан слој - втора половина XX век. .28

Сл. 12 Скопје - ситуација XXI век 29

Сл. 13 Аксонометрија на постојна состојба на Ново маало, Скопје 37

Сл. 14 Улична мрежа-Ново маало; постојна/новопроектирана. 39

Сл. 15 Ситуација на Ново маало. .40

Сл. 16 Декомпозиција на станбен мост .41

Сл. 17 Каталог на станбени единици . .43

Сл. 18 Аксонометрија на предвидена состојба на Ново маало, Скопје .46

Графичките прилози кои несе посебно означени се дело на авторот 